\title{
CFD modeling of oxy-coal combustion: prediction of burnout, volatile and NO precursors release
}

L. Álvarez ${ }^{1}$, M. Gharebaghi ${ }^{2}$, J.M. Jones $^{2}$, M. Pourkashanian ${ }^{2}$, A. Williams ${ }^{2}$, J. Riaza $^{1}$,

$$
\text { C. Pevida }{ }^{1}, \text { J.J. Pis }{ }^{1}, \text { F. Rubiera }{ }^{1 *}
$$

${ }^{1}$ Instituto Nacional del Carbón, INCAR-CSIC, Apartado 73, 33080 Oviedo, Spain

${ }^{2}$ ETII, ERI, University of Leeds, Leeds LS2 9JT, UK

Corresponding author: Tel.: +34985 118 975; Fax: +34 985297662

E-mail address: frubiera@incar.csic.es

\begin{abstract}
The devolatilisation step of coal is a vital stage in both air-coal and oxy-coal combustion and there is interest in whether methods of estimating the reaction parameters are similar for both cases. A network pyrolysis model, the FG-DVC (Functional Group-Depolymerisation Vaporisation Cross-linking) code was employed to evaluate the effect of temperature $(1273-1773 \mathrm{~K})$ and heating rate $\left(10^{4}-10^{6} \mathrm{~K} / \mathrm{s}\right)$ on the devolatilisation parameters of two coals of different rank. The products distribution between char and volatiles, and volatiles and $\mathrm{NH}_{3} / \mathrm{HCN}$ release kinetics were also determined. In order to assess the accuracy of the FG-DVC predictions, the values for nitrogen distribution and devolatilisation kinetics obtained for a temperature of $1273 \mathrm{~K}$ and a heating rate of $10^{5} \mathrm{~K} / \mathrm{s}$ were included as inputs in a Computational Fluid Dynamics (CFD) model for oxy-coal combustion in an entrained flow reactor (EFR). CFD simulations with the programme default devolatilisation kinetics were performed. The oxygen content in oxy-firing conditions ranged between 21 and 35\%, and air-firing conditions were also employed as a reference. The experimental coals burnouts and oxygen concentrations from the EFR experiments were employed to test the accuracy of the CFD model. The temperature profiles, burning rates, char burnout and NO
\end{abstract}


emissions during coal combustion in both air and $\mathrm{O}_{2} / \mathrm{CO}_{2}$ atmospheres were predicted. The predictions obtained when using the CFD model with FG-DVC coal devolatilisation kinetics were much closer to the experimental values than the predictions obtained with the ANSYS Fluent (version 12) program default kinetics. The predicted NO emissions under oxy-firing conditions were in good agreement with the experimental values.

Keywords: FG-DVC code, Computational Fluid Dynamics, Oxy-fuel combustion

\section{Introduction}

A major objective in coal combustion research is the development of comprehensive models to help in the design of combustors and to an efficient utilisation of coal. In this context, Computational Fluid Dynamics (CFD) models have been widely used to simulate combustion in coal-fired power stations [1-3]. A CFD model for coal combustion must consider a number of complex, simultaneous and interdependent processes such as gas and particle phase dynamics, turbulence, heat transfer, pollutant formation and heterogeneous and homogenous chemical reactions [4]. With regard to the latter, three important sub-models must be taken into account: coal particles devolatilisation, volatiles combustion and char combustion. Although devolatilisation takes place in a short time scale of the total combustion process, it has a great impact in the latter stages. Devolatilisation controls the product distribution of tar, char and gases, and it also determines the nitrogen distribution between char and volatiles [5]. It affects as well the porosity and internal surface of the resultant char. As a consequence, ignition, flame stability, char burnout and pollutant formation are influenced by the devolatilisation process [6]. The adequate prediction of the devolatilisation parameters is crucial for its inclusion in a CFD model for coal combustion. The network pyrolysis 
codes, which are based on coal structural network description, offer one of the best ways forward in determining the correct devolatilisation parameters [7].

Oxy-fuel combustion is considered one of the most promising $\mathrm{CO}_{2}$ capture technologies since it could be adapted in conventional steam power plants and in Integrated Gasification Combined Cycle (IGCC) plants as well [8]. During oxy-fuel combustion a mixture of oxygen and recycled flue gas (mainly $\mathrm{CO}_{2}$ and $\mathrm{H}_{2} \mathrm{O}$ ) is used for fuel combustion. Due to the differences in gas properties of $\mathrm{N}_{2}$ and $\mathrm{CO}_{2}$, oxy-fuel combustion differs from conventional air-firing combustion in several aspects, such as heat transfer, flame ignition, pollutant formation or flue gas composition $[9,10] . \mathrm{CO}_{2}$ has a higher specific molar heat than $\mathrm{N}_{2}$, which can cause a decrease on gas and particle temperature for the same oxygen concentration. The propagation speed and stability of the flame may decrease and the unburned carbon content may increase. During the oxyfuel combustion process, this problem can be overcome by increasing the oxygen concentration (up to approximately $30 \%$ ) in order to match the combustion performance achieved in air, in relation to flame temperature, ignition time, heat transfer, gas temperature profile and char burnout. Also a significant reduction of NO emissions was observed under oxy-firing conditions in comparison to air-firing. This NO reduction is partly caused by the suppression of thermal NO due to the absence of atmospheric $\mathrm{N}_{2}$, and to the reduction of $\mathrm{NO}$ to $\mathrm{N}_{2}$ by recycling the NO. Several studies have been carried out in the last years to gain understanding of the oxy-fuel combustion fundamentals, and in specific areas related to CFD $[11,12]$. For the oxy-fuel process, CFD models can be used to asses and optimise full-scale retrofit designs and to provide data on matching air-fired heat duties [13]. In addition, CFD models can also be used as a design tool when trying to improve combustion efficiency, and to identify potential reductions in pollutant formation, such as $\mathrm{NO}_{\mathrm{X}}$ emissions. 
The scope of the present paper was to evaluate by means of a network pyrolysis code, the FG-DVC code, the effect of devolatilisation conditions (temperature and heating rate) on the product and nitrogen distribution for two coals of different rank. Their effect on volatiles and $\mathrm{HCN} / \mathrm{NH}_{3}$ release rate was also evaluated. To asses the accuracy of these predictions, the parameters obtained were employed as inputs in a CFD model for both air and oxy-coal combustion. Experimental results obtained in an entrained flow reactor were employed to validate the CFD model.

\section{Source of experimental data}

Two coals of different rank were employed for the combustion and pyrolysis experiments: an anthracite from Asturias, Spain (AC), and a South African high-volatile bituminous coal (SAB). The proximate and ultimate analyses of the coals are presented in Table 1; they were obtained using a LECO TGA-601 and a LECO CHNS-932, respectively. The accuracy of the nitrogen analysis was $\pm 10 \%$. The coals were ground and sieved to obtain a $75-150 \mu \mathrm{m}$ particle size distribution.

-Table 1 here-

The experimental data were obtained using an EFR whose details have been previously reported [14]. For the combustion experiments, air $\left(21 \% \mathrm{O}_{2} / 79 \% \mathrm{~N}_{2}\right)$ was employed as a reference case and three binary gas mixtures of $\mathrm{O}_{2}$ and $\mathrm{CO}_{2}$ with compositions of $21 \% \mathrm{O}_{2} / 79 \% \mathrm{CO}_{2}, 30 \% \mathrm{O}_{2} / 70 \% \mathrm{CO}_{2}$ and $35 \% \mathrm{O}_{2} / 65 \% \mathrm{CO}_{2}$ were used. The experiments were performed at a heated furnace temperature of $1273 \mathrm{~K}$. The gas flow rate was adjusted to $22.3 \mathrm{~L} / \mathrm{min}$ (at $1273 \mathrm{~K}, 1 \mathrm{~atm}$ ) in order to obtain a particle residence time of $2.5 \mathrm{~s}$ in the EFR. The burnout is defined as the loss of a fuel during its combustion and it was determined using the ash tracer method [15]. The concentrations of NO are reported as dry with an accuracy of $\pm 5 \%$. Chars from the pulverised coals were obtained 
by thermal decomposition in $\mathrm{N}_{2}$ and $\mathrm{CO}_{2}$ atmospheres in the EFR at $1273 \mathrm{~K}$. The chars were analysed in order to determine their nitrogen content.

\section{Modelling approach}

A commercial CFD program, ANSYS Fluent version 12, was used to simulate the oxycoal combustion process in the reaction zone of the EFR [16]. The computations were performed in a three-dimensional structured grid consisting of $\sim 75,000$ cells, whose details have been reported previously [17]. The CFD code solved the appropriate transport equations for the continuous phase, and a Lagrangian approach was used to calculate particle trajectories through the calculated gas field. The RNG k- $\varepsilon$ turbulence model was employed to model the dynamic of the flow. Heat transfer by radiation was accounted for by the Discrete Ordinate Model because of the higher accuracy and smaller optical length of the EFR [18], together with the cell based Weighted-Sum-ofGray-Gases Model (WSGGM) for the radiative properties of the gases. Other researchers have developed specific models for gas radiative properties in oxy-fuel environments $[19,20]$. Yin et al. [21] implemented a new gaseous radiative properties model in CFD simulations in a laboratory-scale 0.8 MW furnace and found little difference in the radiation source in comparison with the WSGGM model. They concluded that the two models made negligible difference in the simulation results when applied to small-scale oxy-fuel combustion modelling, but their implantation is necessary in modelling large-scale oxy-fuel furnaces.

Far from being just another step in the overall reaction, coal particles devolatilisation has a great impact throughout the overall combustion process because it determines the subsequent steps: it is crucial to know the rate and amount of volatiles released in the devolatilisation step as a function of temperature. The simplest approaches for the 
devolatilisation process are empirical and employ global kinetics, where Arrhenius expressions are used to correlate rates of weight loss with temperature. There are other approaches such as the Kobayashi model [22], which considers two competitive rates that control the devolatilisation over different temperature ranges, and despite the complexity of coal's molecular structure, there are several network pyrolysis models that describe the transformation of the coal's chemical structure. These models are the FG-DVC (Functional Group-Depolymerisation Vaporisation Cross-linking) model [23], the FLASHCHAIN model [24], and the CPD (Chemical Percolation Devolatilisation) model [25]. A recent paper by Jovanovic et al. [26] evaluates the effectiveness of different devolatilisation sub-models, in predicting ignition point position for oxy-coal combustion. It concluded that the network devolatilisation models give more accurate results in comparison with standard devolatilisation models.

The FG-DVC model has been widely used in coal combustion simulations to describe gas evolution, elemental and functional group composition of volatiles and char, and also predicts the yield and molecular weight distribution of volatiles and char. In this work the devolatilisation rate of the coal was modelled using a single step first-order Arrhenius reaction together with kinetics parameters $\left(\mathrm{A}, \mathrm{E}_{\mathrm{a}}\right)$ obtained by means of the FG-DVC code. The use of this single-step model has resulted in good predictions before [27]. The FG-DVC code was employed as a pre-processor tool in order to gain knowledge of the release rate of tar and other light species $\left(\mathrm{CH}_{4}, \mathrm{CO}_{2}, \mathrm{CO}, \mathrm{H}_{2} \mathrm{O}\right.$ and/or $\mathrm{H}_{2}$ ) and the evolution of the light nitrogen species, $\mathrm{NH}_{3}$ and $\mathrm{HCN}$, for coals $\mathrm{AC}$ and SAB. The devolatilisation time was of $0.15 \mathrm{~s}$, the initial temperature was set at $373 \mathrm{~K}$ and, to assess the effect of temperature and heating rates, different final temperatures (1273-1773 K) and heating rates $\left(10^{4}-10^{6} \mathrm{~K} \mathrm{~s}^{-1}\right)$ were employed. 
Volatile combustion was simulated using the fraction/PDF chemical approach [28]. PDF tables for both air and oxy-fuel conditions were calculated using the pre-PDF preprocessor of ANSYS Fluent (version 12), and twenty species including chemical species and radicals and intermediate species were included. The Smith intrinsic model was employed for char combustion [29]. Gil et al. [30] determined char reactivity for chars obtained in $\mathrm{N}_{2}$ and $\mathrm{CO}_{2}$ and found no difference in their reactivity, so the same kinetics parameters were employed for char combustion in air and oxy-firing conditions,. The burning model, char combustion kinetics and specific internal surface areas employed in this work are based on the work of Backreedy et al. [4]. In this work the char- $\mathrm{CO}_{2}$ and char $-\mathrm{H}_{2} \mathrm{O}$ gasification reactions were not taken into account in the total combustion rate, because the reaction rate of char with oxygen is much higher at the temperature used $(1273 \mathrm{~K})$ [31]. The devolatilisation and combustion parameters employed in this work are summarised, and compared with the default ANSYS Fluent (version 12) values, in Table 2.

-Table 2 here-

NO simulations were carried out as a post-processor; the successful prediction of NO emissions requires the correct representation of the fluid flow, heat transfer, combustion process and NO chemistry. NO can be formed via the thermal, prompt and fuel-NO mechanisms. For air conditions, the thermal and fuel-NO formation were considered. For the $\mathrm{O}_{2} / \mathrm{CO}_{2}$ conditions, fuel-NO formation was considered to be the dominant mechanism.

The correct estimation of fuel nitrogen split between volatiles and char during coal devolatilisation is crucial when modelling NO formation. So it is the determination of the $\mathrm{HCN} / \mathrm{NH}_{3}$ release rate kinetics from volatiles. The volatile-N is assumed to be converted both to $\mathrm{HCN}$ and $\mathrm{NH}_{3}$, since at the operation conditions $\left(1273 \mathrm{~K}\right.$ and $\left.10^{5} \mathrm{~K} / \mathrm{s}\right)$ 
even in the case of high rank coals, some $\mathrm{NH}_{3}$ would be evolved [32]. $\mathrm{HCN}$ and $\mathrm{NH}_{3}$ are competitively oxidized and reduced to produce $\mathrm{NO}$ and $\mathrm{N}_{2}$ respectively. The kinetics of those gas-phase reactions developed by De Soete [33] have been widely used in NO modelling. Recently an alternative set of kinetics have been suggested by Cao et al. [34]. The char-N was heterogeneously oxidized to NO via an overall reaction to NO with an assumed conversion factor $\eta$ [35]. The empirical factor $\eta$ refers to the conversion of char-N to NO. Jones et al. [36] have shown for different coal chars that at $1273 \mathrm{~K}$ the conversion of char-N to NO during combustion tends to a constant value of $20 \%$ (mass $/ \operatorname{mass} \%$ ). The nitrogen content of the char was determined experimentally and also by means of the FG-DVC code. The volatile-N was assumed to be converted to both $\mathrm{HCN}$ and $\mathrm{NH}_{3}$, and subsequently oxidized and/or reduced to $\mathrm{NO}$ and/or $\mathrm{N}_{2}$, via the mechanism proposed by De Soete [33]. The nitrogen release derived FG-DVC kinetics were obtained for an inert atmosphere.

Mass flow inlets and wall temperature were employed as the boundary conditions to the CFD model. These values are shown in Table 3 and they were obtained from the measurements made during the experiments in the EFR.

-Table 3 here-

\section{FG-DVC results}

The release rate of tar and other light species $\left(\mathrm{CH}_{4}, \mathrm{CO}_{2}, \mathrm{CO}, \mathrm{H}_{2} \mathrm{O}, \mathrm{H}_{2}\right)$ and $\mathrm{NO}$ precursors $\left(\mathrm{HCN}\right.$ and $\left.\mathrm{NH}_{3}\right)$ was computed using the FG-DVC code at a heating rate of $10^{5} \mathrm{~K} / \mathrm{s}$ and a final temperature of $1273 \mathrm{~K}$. This release rate for coals $\mathrm{AC}$ and $\mathrm{SAB}$ is shown in Fig. $1(\mathrm{a}, \mathrm{b})$, whereas the evolution of $\mathrm{HCN}$ and $\mathrm{NH}_{3}$, which is crucial for the formation of NO, is shown in more detail in Fig. 1 (c, d).

-Fig. 1 here- 
The characteristics of the devolatilisation process are fuel specific. The mechanism of coal pyrolysis and products yield has been reviewed in the literature [37-39]. Two stages have been long recognized in coal pyrolysis, primary and secondary pyrolysis. During primary pyrolysis, weak aliphatic bonds in the solid fuel matrix are broken, producing fragments which evolve as tar. Bituminous coals yield large amounts of tar in comparison with anthracitic coals which have a higher initial degree of crosslinking. After the breaking of weak bonds, the functional groups decompose, releasing $\mathrm{CO}_{2}$ and $\mathrm{H}_{2} \mathrm{O}$. The secondary pyrolysis involves decomposition of the char and tar formed during the primary stage, and more gases such as $\mathrm{CH}_{4}, \mathrm{CO}, \mathrm{H}_{2}$ and light nitrogen species (HCN and $\mathrm{NH}_{3}$ ) are released. The secondary pyrolysis takes place at temperatures above 1000 $\mathrm{K}$, and it is strongly rank dependant.

Fuel nitrogen evolution during coal devolatilisation and their implications in $\mathrm{NO}_{\mathrm{X}}$ formation has been extensively reviewed $[5,40]$. The devolatilisation of low rank coals, like $\mathrm{SAB}$, produces more $\mathrm{NH}_{3}$ than $\mathrm{HCN}$ in comparison with the devolatilisation of high rank coals, as can be seen in Fig. 1 (c, d). From those release curves, the volatile and $\mathrm{HCN} / \mathrm{NH}_{3}$ release kinetics would be derived and later employed as inputs in the devolatilisation and NO formation sub-models, respectively.

The FG-DVC code also gives information of the amount of char generated after devolatilisation, i.e., the char yield, and about the fate of fuel nitrogen, i.e., the char-N yield, or the amount of nitrogen that remains in the char. With those yields, the nitrogen content in char and volatiles can be estimated. In Table 4 a comparison between the experimental and predicted nitrogen content is shown. In order to test the accuracy of the FG-DVC predictions, NO emissions will be predicted (see Section 5) with both nitrogen values as inputs in the NO formation sub-model. 
In Fig 1 we have shown the composition of the volatiles as a function of rank, but as $\mathrm{Yu}$ et al. [40] have pointed out, the yield of devolatilisation products is strongly dependant on heating rate and temperature. The char and char-N yields for coals $\mathrm{AC}$ and $\mathrm{SAB}$ were obtained for different heating rates $\left(10^{4}-10^{6} \mathrm{~K} / \mathrm{s}\right)$ and temperatures $(1273-1773 \mathrm{~K})$, and they are shown in Fig. 2.

-Fig. 2 here-

Coal $\mathrm{AC}$ has a lower volatile matter content than $\mathrm{SAB}$, so its char yield is higher than that of coal SAB for all the cases studied, as can be seen in Fig. $1(a, b)$. With increasing heating rates, the release of volatiles is enhanced causing the char yield to decrease for both coals. Also, increasing the temperature from 1273 to $1523 \mathrm{~K}$ made the char yield to decrease, but in a lesser extent than heating rate, however, no differences were observed between the values for 1523 and $1773 \mathrm{~K}$.

Fig. 2 (c, d) show the effect of heating rate and temperature on N-char yield for AC and $\mathrm{SAB}$. As expected, the N-char yield follows the same trend as the char yield because the release of nitrogen intermediates $\left(\mathrm{NH}_{3}\right.$ and $\left.\mathrm{HCN}\right)$ is closely related to the release of volatiles. High heating rates seem to enhance the release of nitrogen, i.e., lower N-char yield, and previous research [41-43] has found an initial enrichment of nitrogen in the char in the temperature range $600-1200 \mathrm{~K}$, while at high temperature nitrogen is depleted from the char. In Table 5, the estimated values for char and volatile content are shown. It can be seen that the char is depleted in nitrogen as the heating rate and temperature increase. The opposite trend is observed for the volatiles nitrogen content.

-Table 5 here-

Also the coal devolatilisation kinetics parameters $\left(A, E_{a}\right)$ were derived using the calculated tar rate obtained with the FG-DVC code. For a first order Arrhenius reaction, the rate expression of volatile release can be expressed as follows: 


$$
\frac{-1}{W} \frac{d W}{d t}=K=A \exp \left(\frac{-E a}{R T}\right)
$$

where $\mathrm{K}$ is the devolatilisation rate constant, $\mathrm{A}$ is the preexponential factor, $\mathrm{Ea}$ is the activation energy and $\mathrm{W}$ is the mass of volatiles.

The values of $\mathrm{dW} / \mathrm{dt}$ and $\mathrm{W}$ can be obtained from the data given by the FG-DVC code. The values of the kinetics parameters obtained $\left(\mathrm{A}, \mathrm{E}_{\mathrm{a}}\right)$ for coals $\mathrm{AC}$ and $\mathrm{SAB}$ are shown in Tables 6 and 7, respectively. The volatile release kinetics parameters for a temperature of $1273 \mathrm{~K}$ and a heating rate of $10^{5} \mathrm{~K} / \mathrm{s}$ were employed as inputs in the CFD devolatilisation submodel. In industrial power generation boilers, the combustion conditions are much more severe than those of the present work, but it is not feasible to carry out devolatilisation tests in an industrial power boiler. So, in the event of modelling coal combustion in an industrial power boiler, volatiles and $\mathrm{HCN} / \mathrm{NH}_{3}$ release kinetics must be estimated. Also the product distribution showed in Fig. 2 must be taken into account. Previous researchers have modelled successfully coal combustion in power stations using FG-DVC derived kinetics [6, 44]. The coal release kinetics parameters for coals $\mathrm{AC}$ and $\mathrm{SAB}$ for different heating rates $\left(10^{4}-10^{6} \mathrm{~K} / \mathrm{s}\right)$ and temperatures (1273-1773 K) were also obtained by means of the FG-DVC and they are shown in Tables 6 and 7.

-Tables 6 and 7 here-

For all the conditions studied, the values of the activation energy of the bituminous coal, $\mathrm{SAB}$, are lower than those of the anthracite, $\mathrm{AC}$. Lower values of the activation energy indicate higher volatiles release rates. The kinetics parameters $(\mathrm{A}, \mathrm{Ea})$ are highly dependent on heating rate and temperature. With higher heating rates the activation energy $\left(\mathrm{E}_{\mathrm{a}}\right)$ decreases; this reduction, and the associate increase in the volatiles release, is not the same for all the temperatures studied. For both coals the activation energy values at $1773 \mathrm{~K}$ are quite similar at any heating rate, which indicates that heating rate 
has a higher impact on the volatiles release rate at relatively low temperatures (1273$1523 \mathrm{~K})$. A similar trend is observed when the effect of temperature is considered, at higher temperatures there is a reduction in the value of the activation energy. Also, the effect of temperature is more remarkable at low heating rates $\left(10^{4}-10^{5} \mathrm{~K} / \mathrm{s}\right)$ especially for the bituminous coal, SAB. It is necessary to take into account that the FG-DVC predictions for volatiles release kinetics were determined for an inert atmosphere. Rathmann et al. [45] carried out pyrolysis experiments in $\mathrm{N}_{2}$ and $\mathrm{CO}_{2}$ atmospheres and they showed the influence of the char- $\mathrm{CO}_{2}$ reaction at temperatures above $1050 \mathrm{~K}$. The volatiles release rate is not affected, although at the latter stages of combustion there can be certain char gasification with $\mathrm{CO}_{2}$. In this work we have employed the same devolatilisation kinetics for air and oxy-firing CFD simulations and then the predicted results were contrasted against the experimental data.

During coal devolatilisation, the light nitrogen species ( $\mathrm{HCN}$ and $\mathrm{NH}_{3}$ ) evolved comparatively late in the devolatilisation step and their release rate is much lower than for other volatile species (such as $\mathrm{CH}_{4}, \mathrm{H}_{2}, \mathrm{CO}$, etc), as shown in Figure 1. Most of the nitrogen released during the primary coal pryrolysis (about $85-100 \%$ ) does so in the form of aromatic compounds in tars; the fraction released as light gases is negligible. During secondary pyrolysis, the heteroaromatic rings of the tar decompose, releasing the nitrogen as $\mathrm{HCN}$ and/or $\mathrm{NH}_{3}$ (depending on the conditions and on the rank of the coal) to the gas-phase. The release of char nitrogen takes place at longer time scales and higher temperatures. So, it can be stated that nearly all the nitrogen released during coal pyrolysis comes from the tar. When modelling $\mathrm{NO}_{\mathrm{X}}$ emissions during coal combustion, the relation between $\mathrm{HCN}$ and $\mathrm{NH}_{3}$ release rates is crucial to estimate $\mathrm{NO}$ formation from the volatile-N. In this study, a first-order Arrhenius kinetic was employed to determine the kinetics of the thermal cracking of tar- $\mathrm{N}$ to form $\mathrm{HCN}$ and/or $\mathrm{NH}_{3}$. 
Results are shown in Tables 8 and 9 for coals AC and SAB, respectively. The FG-DVC predicted $\mathrm{NH}_{3} / \mathrm{HCN}$ release kinetics were also determined for an inert atmosphere. Duan et al. [46] carried out pyrolysis experiments under inert and $\mathrm{CO}_{2}$ atmospheres and found some differences in the $\mathrm{HCN} / \mathrm{NH}_{3}$ release ratio.

-Tables 8 and 9 here-

Tables 8 and 9 show the predicted $\mathrm{NH}_{3}$ and $\mathrm{HCN}$ release kinetics at different temperatures $(1273-1773 \mathrm{~K})$ and heating rates $\left(10^{4}-10^{6} \mathrm{~K} / \mathrm{s}\right)$ for coals $\mathrm{AC}$ and $\mathrm{SAB}$, respectively. For both coals, the heating rate barely affects the activation energies $\left(\mathrm{Ea}_{\mathrm{NH} 3}\right.$ and $\left.\mathrm{Ea}_{\mathrm{HCN}}\right)$. For all the cases studied, $\mathrm{Ea}_{\mathrm{NH} 3}$ is lower than $\mathrm{Ea}_{\mathrm{HCN}}$, which indicates that at low temperatures $\mathrm{NH}_{3}$ release is more favoured than $\mathrm{HCN}$ release. During coal pyrolysis, both at low and high heating rates, $\mathrm{NH}_{3}$ has been detected prior to $\mathrm{HCN}$ [5]. The nitrogen in the tar is largely incorporated in the same structures as in the parent coal, i.e., mainly in pyrrolic and pyridinic structures. The thermal stability of pyrrolic structures in the tar is lower than that of pyridinic structures, so a higher pyrolysis temperature is required to release nitrogen as $\mathrm{HCN}$ from pyridine groups than from pyrrole groups. Other researchers $[47,48]$ have reported values for the activation energy for tar-N release ranging from 140 to $220 \mathrm{~kJ} / \mathrm{mol}$, which are in good agreement with the values obtained in this work. As it can be seen in Table 8 for coal $\mathrm{AC}, \mathrm{Ea}_{\mathrm{NH} 3}$ barely changed with temperature whereas the value of $\mathrm{Ea}_{\mathrm{HCN}}$, at any heating rate, decreased with increasing temperatures. Although this decrease was not great, it indicated an enhancement of $\mathrm{HCN}$ release with temperature. Also, the greater increase of $\mathrm{A}_{\mathrm{HCN}}$, when compared with that of $\mathrm{A}_{\mathrm{NH} 3}$ with increasing heating rates and temperatures, indicates that $\mathrm{HCN}$ release is more favoured than $\mathrm{NH}_{3}$ at high heating rates and temperatures. Similar conclusions can be extracted for coal SAB, as it can be deduced from the data shown in Table 9. 


\section{CFD results}

\subsection{Experimental data used to validate the CFD model}

To validate the CFD model the experimental burnouts and NO concentrations obtained in the EFR reactor were employed. Entrained flow reactors are very useful to enable more detailed CFD models to be validated and improved. Residence times and particle heating rates in entrained flow reactors are similar to those occurring in industrial combustors. As can be seen in Backreedy et al. [49], the numerical predicted particle residences time for most of the particles inside an industrial coal combustor is not higher than 3-4 s.

Coals $\mathrm{AC}$ and $\mathrm{SAB}$ were burned under different levels of excess oxygen for each atmosphere studied, air and three defined $\mathrm{O}_{2} / \mathrm{CO}_{2}$ atmospheres. A particle residence time of $2.5 \mathrm{~s}$ and a temperature of $1273 \mathrm{~K}$ were used in all experiments. The equivalence ratio, defined as the ratio between the coal mass flow and the stoichiometric value, was used to determine the excess oxygen during combustion.

The $\mathrm{AC}$ and $\mathrm{SAB}$ burnouts are shown in Fig. 3. It can be seen that the burnout value decreased as the equivalence ratio increased due to the fact that less oxygen was available at high equivalence ratio values. At high oxygen excess (low equivalence ratio values), the $\mathrm{SAB}$ burnout curves showed an asymptotic approach towards a value of $100 \%$. Whereas, AC burnout showed an almost linear dependence on the equivalence ratio in both air and oxyfuel conditions. Even at low equivalence ratio values, the anthracite $\mathrm{AC}$ showed low burnout values, reflecting the lower reactivity of high rank coals.

-Fig 3 here- 
For both coals, the burnout obtained with $21 \% \mathrm{O}_{2} / 79 \% \mathrm{CO}_{2}$ was lower than that reached under $21 \% \mathrm{O}_{2} / 79 \% \mathrm{~N}_{2}$ due to differences in gas composition (density), heat capacity and radiative properties. These differences lead to a decrease in gas and particle temperatures, causing the combustion rate of the char and the coal burnout to fall $[50$, 51]. Under $30 \% \mathrm{O}_{2} / 70 \% \mathrm{CO}_{2}$ and $35 \% \mathrm{O}_{2} / 65 \% \mathrm{CO}_{2}$ atmospheres, the burnout achieved was higher than in air, since the higher oxygen concentration produced an increase in the char combustion rate. For coal AC, more significant differences were observed between the different atmospheres studied, whereas for coal SAB these differences were less obvious because it reached a very high burnout under all conditions due to its high reactivity.

The NO concentrations (in ppm, dry gas) of $\mathrm{AC}$ and $\mathrm{SAB}$ under the different atmospheres employed are shown in Fig. 4. For both coals, a decrease in NO emissions was observed for the $21 \% \mathrm{O}_{2} / 79 \% \mathrm{CO}_{2}$ atmosphere in comparison with $21 \% \mathrm{O}_{2} / 79 \% \mathrm{~N}_{2}$. Under oxyfuel conditions there is an enhancement in the reduction of NO probably due to the higher $\mathrm{CO}$ concentrations than in air combustion. It can also be seen in Fig. 4 an increase in NO concentration with the increase of oxygen concentration in $30 \% \mathrm{O}_{2} / 70 \% \mathrm{CO}_{2}$ and $35 \% \mathrm{O}_{2} / 65 \% \mathrm{CO}_{2}$ atmospheres, since higher oxygen concentrations increase the char burning rate, and therefore of $\mathrm{NO}$ emission rate from char-N as observed by other authors $[52,53]$.

-Fig. 4 here-

NO emissions are quite dependant on the nitrogen content of the fuel. Coal AC with lower nitrogen content produces less NO than coal SAB. Besides the rank of the coal, the equivalence ratio also affects the NO formation. As shown by Hu et al. [54], the NO emissions produced during the combustion of bituminous coals are higher for fuel lean conditions due to the oxidizing atmosphere, and they are lower for fuel rich conditions 
because the reducing atmosphere favours the reduction of NO to molecular nitrogen by homogenous and heterogeneous reactions. But in the case of $\mathrm{AC}$ combustion, the NO emissions are not as dependant on the value of the equivalence ratio as in the case of $\mathrm{SAB}$. The lower volatile content of $\mathrm{AC}$ implies it has less potential for the reduction of NO emissions $[55,56]$.

In Table 10 the burnout and NO emissions values for an equivalence ratio of $0.8(25 \%$ oxygen excess) are shown. These results were interpolated from Figs. 3 and 4 and were used to validate the CFD model developed for air and oxy-firing combustion.

-Table 10-

\subsection{Computed results}

Simulations for the two coals in air and defined $\mathrm{O}_{2} / \mathrm{CO}_{2}\left(21-35 \% \mathrm{O}_{2}\right)$ environments have been performed. The oxygen excess was set at $25 \%$, which corresponds to an equivalence ratio of 0.8 . Fig. 5 presents the predicted temperature, burning rate and $\mathrm{O}_{2}$ profiles for the upper part of the reaction zone during SAB combustion. In this figure the term CFD predictions refers to the numerical predictions obtained with the commercial ANSYS Fluent model with default parameters, while Model predictions refers to the numerical predictions obtained when the CFD model was run using as inputs the combustion and FG-DVC derived devolatilisation kinetics parameters, which are described in Section 3 and summarized in Table 2.

-Fig. 5 here-

As can be seen in Fig. 5 (a) and (d), when air (case I) is replaced by $21 \% \mathrm{O}_{2} / 79 \% \mathrm{CO}_{2}$ (case II), gas temperatures dropped significantly. $\mathrm{CO}_{2}$ has a higher specific molar heat than $\mathrm{N}_{2}$, which implies that when $\mathrm{N}_{2}$ is replaced by $\mathrm{CO}_{2}$ for the same oxygen concentration, the specific heat capacity of the gases decreases, leading to lower flame and gas temperatures. Therefore, the particle temperature during the $21 \% \mathrm{O}_{2} / 79 \% \mathrm{CO}_{2}$ 
atmosphere is expected to be lower, causing the combustion rate of the char to fall, as shown in Fig. 5 (b) and (e). Also, the lower diffusivity of $\mathrm{O}_{2}$ in $\mathrm{CO}_{2}$ than in $\mathrm{N}_{2}$ affects the transport of $\mathrm{O}_{2}$ to the surface of the particles, leading to a reduced combustion of the volatiles released from the coal particles and to reduced char combustion rates under oxy-fuel conditions than in air. There are differences in the combustion behaviour under air and oxy-fuel conditions. In Figs. 5 (c) and (f) the variation of $\mathrm{O}_{2}$ concentration inside the EFR is shown. This figure indicates that under oxy-fuel conditions, combustion takes place closer to the injection zone. This is because after coal devolatilisation (and subsequent consumption of oxygen by the volatiles) the char- $\mathrm{CO}_{2}$ reaction takes place in some extent. The predicted rates confirmed that although char combustion in $21 \% \mathrm{O}_{2} / 79 \% \mathrm{CO}_{2}$ (case II) starts earlier than in air (case I), their char burning rates are lower, which suggests that the higher $\mathrm{CO}_{2}$ concentration do not improve the char reaction rate in the temperature range of this study. In the upper zone of the EFR, where devolatilisation takes places, under oxy-firing conditions the $\mathrm{CO}$ concentrations are much higher than in air-firing conditions. In this zone, the higher $\mathrm{CO}$ concentrations would enhance the reduction of the NO formed from the volatiles. In the rest of the EFR, for both air and oxy-firing conditions, CO concentrations are quite similar and low, which indicates that char- $\mathrm{CO}_{2}$ reaction is negligible.

As it can be observed in Fig. 5, with increasing oxygen concentration in $\mathrm{O}_{2} / \mathrm{CO}_{2}$ atmospheres (cases III and IV), an increase in burning rate, temperature and oxygen consumption rate is attained. Increasing the $\mathrm{O}_{2}$ percentage in $\mathrm{CO}_{2}$ up to $30 \%$ is still insufficient to match the specific heat capacity of the air. According to Zhang et al. [57], the specific heat capacity is one of the principal factors affecting the char surface temperature for any given $\mathrm{O}_{2}$ fraction. However, under the $30 \% \mathrm{O}_{2} / 70 \% \mathrm{CO}_{2}$ and $35 \% \mathrm{O}_{2} / 65 \% \mathrm{CO}_{2}$ atmospheres, the burning rate was higher than in air, since it is likely 
that the increase in the mass flux rate of $\mathrm{O}_{2}$ promotes the consumption rate of volatiles, providing extra heat feedback to the coal particles to enhance their devolatilisation and combustion.

Although the temperatures profiles showed in Fig. 5 (a) followed the same trend as those shown in Fig. 5 (d), the temperatures predicted with the CFD model with default parameters, Fig 5 (a), are much higher. Burning rate and oxygen consumption are closely related to temperature, therefore as can be seen in Fig. 5 (b) the predicted burning rate profiles are much higher than those shown in Fig. 5 (e), and so is the oxygen consumption shown in Fig. 5 (c) in comparison with that of Fig. 5 (f). Experimental burnouts and oxygen concentrations for an oxygen excess of $25 \%$ (which corresponds to an equivalence ratio of 0.8 ) were employed to validate the model, and a comparison between the experimental and predicted values is shown in Fig. 6. The burnouts predicted with the CFD model with defaults parameters were higher in all the cases. However, when the CFD model with the parameters of Table 2 was employed, a better agreement between experimental and numerical burnout values was obtained. This is due to the fact that Fluent uses, by default, devolatilisation values obtained for coals of lower rank than that of the coals employed in this work. As can be seen in Table 2, for SAB devolatilisation the default value for the activation energy was 74.0 $\mathrm{kJ} / \mathrm{mol}$, whereas the value predicted by FG-DVC was $155.9 \mathrm{~kJ} / \mathrm{mol}$. The use of the default kinetics leads to an over-prediction in the temperature profiles, and, as a consequence, in coal burnout and oxygen concentration.

-Fig. 6 here-

Fig. 7 presents the predicted temperature, burning rate and $\mathrm{O}_{2}$ profiles for the upper part of the reaction zone during $\mathrm{AC}$ combustion. The temperature profiles predicted for AC differ greatly to those of SAB. These differences are due to the lower volatile content of 
$\mathrm{AC}$, which releases less volatiles during devolatilisation, Thus, the temperature values in the upper zone of the reactor, where devolatilisation takes place, are lower. Similar trends are observed for the burning rate and the oxygen concentration profiles. In the case of SAB, due to its higher volatile matter content, the oxygen is consumed rapidly during the combustion of volatiles and the burning rate is higher than that of AC.

-Fig 7-

For AC the differences between CFD predictions and the Model predictions depicted in Fig. 7, are much higher than in the case of SAB. The activation energy value predicted by FG-DVC for AC is $228.6 \mathrm{~kJ} / \mathrm{mol}$ whereas the value given by ANSYS Fluent (version 12) as default is $74.0 \mathrm{~kJ} / \mathrm{mol}$, and this is the cause of the marked differences in the predictions made by both models. Experimental burnouts and oxygen concentrations for an oxygen excess of $25 \%$ obtained during $\mathrm{AC}$ combustion in the EFR were employed to validate the model. A comparison between the experimental and predicted values is shown in Fig. 8. It can be seen that the predictions made with the CFD model with default parameters greatly differ from the experimental values. Thus, in order to model combustion of high rank coals, the need for accurate kinetics parameters is much more critical than in the case of low rank coals.

-Fig. 8-

Finally, NO simulations were carried out as a post-processing stage using the model predictions with the FG-DVC kinetics. Table 10 compares the experimental and predicted NO emissions results at the outlet of the EFR, during $\mathrm{AC}$ and $\mathrm{SAB}$ combustion. Prediction 1 refers to the numerical NO predictions obtained when using as inputs the nitrogen content of char and volatiles determined experimentally. Prediction 2 refers to the predicted values of NO when using the nitrogen content of char and volatiles determined by means of the FG-DVC code. 
-Table 11 here-

As it can be seen in Table 11, both experimental and predicted results followed the same trend. A decrease in $\mathrm{NO}$ emissions is observed during combustion in $21 \% \mathrm{O}_{2} / 79 \% \mathrm{CO}_{2}$ in comparison with the combustion in air, and an increase in NO emissions with higher $\mathrm{O}_{2}$ concentration in the $\mathrm{CO}_{2}$ mixture. In general, good agreement between the experimental and numerical results was obtained, except in the case of combustion of coal $\mathrm{SAB}$ in air. In this case, NO emissions were slightly over-predicted due to inaccuracies in thermal NO prediction. Thermal-NO formation is highly dependent on temperature. Therefore, inaccuracies in temperature prediction could lead to inaccuracies in NO predictions. As can be seen in Table 10, the accurate determination of the nitrogen partition between char in volatiles is crucial when modelling NO emissions. Chui et al. [58] have shown that the model NO estimations can be greatly affected by the distribution of fuel-N between char and volatiles. The predicted NO emissions obtained when using FG-DVC derived data are close to the experimental values. This is of the highest importance when modelling NO formation in power station boilers where no experimental data of nitrogen distribution can be provided.

The use of this CFD model for an oxy-fuel combustion design is possible but some minor changes should be made. An appropriate mesh of the combustion chamber must be built, and the turbulence has to be properly modelled. Gharebaghi et al. [59] have performed large eddy simulation (LES) for oxy-firing conditions in a 1 MWth combustion test facility and they have obtained more realistic prediction of the shape and the physicial properties of the flame than for RANS simulations. Also for large combustors and high temperatures, the importance of the radiation source term increases, and it would be advisable to use specific oxy-fuel radiation models [21]. The scope of the present paper was to evaluate the effect of the devolatilisation conditions 
on the product and nitrogen distribution by means of the FG-DVC code. The predictions were validated with the experimental results at $1273 \mathrm{~K}$ and a heating rate of $10^{5} \mathrm{~K} / \mathrm{s}$. In the event of modelling an industrial combustor, the devolatilisation behaviour of the coals can be easily predicted using the FG-DVC code.

\section{Conclusions}

A FG-DVC code was employed to study the effect of temperature and heating rate on the devolatilisation parameters for an anthracite and a high volatile bituminous coal. The coal devolatilisation kinetics obtained for a temperature of $1273 \mathrm{~K}$ and a heating rate of $10^{5} \mathrm{~K} / \mathrm{s}$ were employed as inputs in the devolatilisation submodel of a CFD model for oxy-coal combustion. The predicted nitrogen distribution between char and volatiles were used in the NO formation submodel.

The predicted values for coal burnout and oxygen concentration obtained when using the FG-DVC coal devolatilisation kinetics, were found to be much closer to the experimental values obtained in the EFR, than the values obtained when using the ANSYS Fluent (version 12) default devolatilisation kinetics. Once the CFD model for oxy-coal combustion was validated, simulations for NO formation were carried out as a post-processor. The predicted NO emissions showed the importance of an accurate determination of fuel-nitrogen distribution between char and volatiles when modelling NO formation.

From all the evidence available it is apparent that the FG-DVC predictions of coal devolatilisation and fuel-nitrogen distribution are also applicable under oxy-firing conditions. The use of this code can be of great importance when modelling oxy-coal combustion in an industrial power boiler where no experimental data of coals devolatilisation and nitrogen species evolution can be obtained. 


\section{Acknowledgements}

The present study was carried out with financial support from the Spanish MICINN (Project PS-120000-2005-2) co-financed by the European Regional Development Fund. L.A. and J.R. acknowledge funding from the CSIC JAE program, which was cofinanced by the European Social Fund, and the Asturias Regional Government (PCTI program), respectively. MG acknowledges financial support from E.ON UK, and for an EPSRC Dorothy Hodgkin Postgraduate Award. We also thank Dr L Ma for helpful discussions.

\section{References}

1. Pallarés J, Gil A, Cortés C, Herce C. Numerical study of co-firing coal and Cynara cardunculus in a 350 MWe utility boiler. Fuel Processing Technology 2009; 90: 1207-13.

2. Choi $\mathrm{CR}, \mathrm{Kim} \mathrm{CN}$. Numerical investigation on the flow, combustion and $\mathrm{NO}_{\mathrm{X}}$ emission characteristics in a $500 \mathrm{MW}_{\mathrm{e}}$ tangentially fired pulverized-coal boiler. Fuel 2009; 88: 1720-31.

3. Ren F, Li Z, Liu G, Chen Z, Zu Q. Numerical Simulation of flow and combustion characteristics in a 300 MWe down-fired boiler with different OFA angles. Energy and Fuels 2011; 25: 1457-64.

4. Backreedy RI, Fletcher LM, Ma L, Pourkashanian M, Williams A. Modelling pulverised coal combustion using a detailed coal combustion model. Combustion Science and Technology 2006; 178: 763-87.

5. Glarborg P, Jensen AD, Johnsson JE. Fuel nitrogen conversion in solid fuel fired systems, Progress in Energy and Combustion Science 2003; 29: 89-113.

6. Wendt JOL. Fundamental coal combustion mechanisms and pollutant formation in furnaces. Progress in Energy and Combustion Science 1980; 6: 201-22. 
7. Solomon PR, Hamblen DG, Yu Z-Z, Serio MA. Network models of coal thermal decomposition. Fuel 1990; 69: 754-63.

8. Kunze C, Spliethoff H. Assesment of oxy-fuel, pre- and post-combustion-based carbon capture for future IGCC plants. Applied Energy 2012; 94: 109-16.

9. Scheffknech Gt, Al-Makhadmeh L, Schnell U, Maier J. Oxy-fuel coal combustion-A review of the current state-of-the-art. International Journal of Greenhouse Gas Control 2011; 5: 16-35.

10. Hu Y, Yan J. Characterization of flue gas in oxy-coal combustion processes for $\mathrm{CO}_{2}$ capture. Applied Energy 2012; 90: 113-21.

11. Chen L, Yong SZ, Ghoniem AF. Oxy-fuel combustion of pulverized coal: Characterization, fundamentals, stabilization and CFD modelling. Progress in Energy and Combustion Science 2012; 38: 156-214.

12. Holtmeyer ML, Kumfer B, Axelbaum RL. Effects of particle size during cofiring under air-fired and oxyfuel conditions. Applied Energy 2012, 93: 60613.

13. Edge P, Heggs PJ, Pourkashanian M, Stephenson PL, Williams A. A reduced order full plant model for oxyfuel combustion. Fuel 2012, 101: 234-43.

14. Arias B, Pevida C, Rubiera F, Pis JJ. Effect of biomass blending on coal ignition and burnout during oxy-fuel combustion. Fuel 2008; 87:2753-59.

15. Badzioch S, Hawksley PGW. Kinetics of thermal decomposition of pulverized coal particles. Industrial and Engineering Chemistry Process Design and Development. 1970; 9: 521-30.

16. ANSYS FLUENT, 2009. Version 12, Ansys Inc. USA,

17. Álvarez L, Gharebaghi M, Pourkashanian M, Williams A, Riaza J, Pevida C, Pis JJ, Rubiera F. CFD Modelling of oxy-coal combustion in an entrained flow reactor. Fuel Processing Technology 2011; 92: 1489-97. 
18. Ma L, Gharebaghi M, Porter R, Pourkashanian M, Jones JM, Williams A. Modelling methods for co-fired pulverised fuel furnace. Fuel 2009; 88: 2448-54.

19. Porter R, Liu F, Pourkashanian M, Williams A, Smith D. Evaluation of solution methods for radiative heat transfer in gaseous oxy-fuel combustion environments. Journal of Quantitative Spectroscopy and Radiative Transfer 2010; 111: 2084-94.

20. Johansson R, Andersson K, Leckner B, Thunman H. Models for gaseous radiative heat transfer applied to oxy-fuel conditions in boilers. International Journal of Heat and Mass Transfer 2010; 53: 220-30.

21. Yin C, Rosendahl LA, Kær SK. Chemistry and radiation in oxy-fuel combustion: A computational fluid dynamics modelling study. Fuel 2011; 90: 2519-29.

22. Kobayashi H, Howard JB Sarofim AF. Coal devolatilisation at high temperatures. Symposium (International) on Combustion 1976; 16: 411-25.

23. Solomon PR, Fletcher TH. Impact of coal pyrolysis on combustion. Symposium (International) on Combustion 1994; 15: 463-74.

24. Niksa S. FLASHCHAIN Theory for rapid coal devolatilization kinetics. 5. interpreting rates of devolatilization for various coal types and operating conditions. Energy and Fuels 1994; 8: 671-79.

25. Fletcher TH, Kerstein AR, Pugmire RJ, Grant DM. Chemical percolation model for devolatilisation: 2. Temperature and heating rate effects on products yield. Energy and Fuels 1990; 6: 4-54.

26. Jovanoviv R, Milewska A Swiatkoswi B, Goanta A, Splietthoff H. Sensitivity analysis of different devolatilisation models on predicting ignition point position during pulverized coal combustion in $\mathrm{O}_{2} / \mathrm{N}_{2}$ and $\mathrm{O}_{2} / \mathrm{CO}_{2}$ atmospheres. Fuel 2012, 101: 23-37.

27. Jones JM, Patterson PM, Pourkashanian M, Williams A, Arenillas A, Rubiera F, Pis JJ. Modelling $\mathrm{NO}_{\mathrm{X}}$ formation in coal particle combustion at high 
temperature: an investigation of the devolatilisation factors. Fuel 1999; 78: 1171-79.

28. Sivanathu YR, Gaeth GM. Generalized state relationships for scalar properties in non-premixed hydrocarbons/air flames. Combustion and Flame 1990; 82: 211-30.

29. Smith IW. The combustion rates of coal chars: a review. Symposium (International) on Combustion 1982; 19: 1045-65.

30. Gil MV, Riaza J, Álvarez L, Pevida C, Pis JJ, Rubiera F. Oxy-fuel combustion kinetics and morphology of coal chars obtained in $\mathrm{N}_{2}$ and $\mathrm{CO}_{2}$ atmospheres in an entrained flow reactor. Applied Energy 2012; 91: 67-74.

31. Hecht ES, Shaddix CR, Molina A, Haynes BS. Effect of $\mathrm{CO}_{2}$ gasification reaction on oxy-combustion of pulverized coal char. Proceedings of the Combustion Institute 2011; 33: 1699-706.

32. Nelson PF, Buckley AN, Kelly MD. Functional forms of nitrogen in coals and the release of coal nitrogen as $\mathrm{NO}_{\mathrm{X}}$ precursors $\left(\mathrm{HCN}\right.$ and $\mathrm{NH}_{3}$ ). Symposium (International) on Combustion 1992; 24: 1259-67.

33. De Soete GG. Overall reaction rates of $\mathrm{NO}$ and $\mathrm{N}_{2}$ formation from fuel nitrogen. Symposium (International) on Combustion 1975; 15: 1093-102.

34. Nelson PF, Buckley AN, Kelly MD. Functional forms of nitrogen in coals and the release of coal nitrogen as $\mathrm{NO}_{\mathrm{X}}$ precursors $\left(\mathrm{HCN}\right.$ and $\mathrm{NH}_{3}$ ). Symposium (International) on Combustion 1992; 24: 1259-67.

35. Cao H, Sung S, Liu Y, Wall TF. Computational Fluid Dynamics modelling of NOx reduction mechanism in oxy-fuel combustion, Energy and Fuels 2010; 24: 131-35.

36. Lockwood FC, Romo-Miralles CA. Mathematical modelling of fuel-NO emissions from PF burners. Journal of the Institute of Energy 1992; 65: 144-52. 
37. Jones JM, Pourkashanian M, Williams A, Rowlands L, Zhu Q, Thomas KM. Conversion of char nitrogen to NO during combustion. Journal of the Energy Institute 2004; 77: 82-89.

38. Saxena SC. Devolatilization and combustion characteristics of coal particles. Progress in Energy and Combustion Science 1990; 16: 16-55.

39. Solomon PR, Serio MA, Suuberg EM. Coal pyrolysis: experiments, kinetics rates and mechanisms. Progress in Energy and Combustion Science 1992; 18: 133-220.

40. Yu J, Lucas JA, Wall TF. Formation of the structure of chars during devolatilisation of pulverized coal and its thermoproperties: A review. Progress in Energy and Combustion Science 2007; 33: 135-70.

41. Leppälahti J, Koljonen T. Nitrogen evolution from coal, peat and wood during gasification: Literature review. Fuel Processing Technology 1995; 43: 1-45.

42. Kambara S, Takarada T, Yamamoto Y, Kato K. Relation between functional forms of coal nitrogen and formation of $\mathrm{NO}_{\mathrm{X}}$ precursors during rapid pyrolysis, Energy and Fuels 1993; 7: 1013-20.

43. Solomon PR, Colket MB. Evolution of fuel nitrogen in coal devolatilisation. Fuel 1978; 57: 749-55.

44. Backreedy RI, Jones JM, Pourkashanian M, Williams A, Arenillas A, Arias B, Pis JJ, Rubiera F. Prediction of unburned carbon and $\mathrm{NO}_{\mathrm{X}}$ emissions in a tangentially fired power station. Fuel 2005; 84: 2196-203.

45. Rathman RK, Elliot LK, Wall TF, Liu Y, Moghtaderi B. Differences in reactivity of pulverised coal in air $\left(\mathrm{O}_{2} / \mathrm{N}_{2}\right)$ and oxy-fuel conditions $\left(\mathrm{O}_{2} / \mathrm{CO}_{2}\right)$. Fuel Processing Technology 2009; 90: 797-802.

46. Duan L, Zhao C, Ren Q, Wu Z, Chen X. NOx precursors evolution during coal heating process in $\mathrm{CO}_{2}$ atmosphere. Fuel 2011; 90: 1668-73. 
47. Ledesma EB, Li C-Z, Nelson PF, Mackie JC. Release of HCN, NH3, and HNCO from the thermal gas-phase cracking of coal pyrolysis tars. Energy and Fuels 1998; 12: 536-41.

48. Zhang H, Fletcher TH. Nitrogen transformations during secondary coal pyrolysis, Energy and Fuels 2001; 15: 1512-22.

49. Backreedy RI, Fletcher LM, Jones JM, Ma L, Pourkashanian M, Williams A. Co-firing coal and biomass: a modeling approach. Proceedings of the Combustion Institute 2005; 30: 2955-64.

50. Riaza J, Álvarez L, Gil MV, Pevida C, Pis JJ, Rubiera F. Effect of oxy-fuel combustion with steam addition on coal ignition and burnout in an entrained flow reactor. Energy 2011; 36: 5314-19.

51. Berejano PA, Levendis YA. Single-coal particle combustion in $\mathrm{O}_{2} / \mathrm{N}_{2}$ and $\mathrm{O}_{2} / \mathrm{CO}_{2}$ environments. Combustion and Flame 2008; 153: 270-87.

52. Shaddix CR, Molina A. Fundamental investigation of $\mathrm{NO}_{\mathrm{X}}$ formation during oxy-fuel combustion of pulverized coal. Proceedings of the Combustion Institute 2011; 33: 1723-30.

53. Croiset E, Thambimuthu KV. $\mathrm{NO}_{\mathrm{X}}$ and $\mathrm{SO}_{2}$ emissions from $\mathrm{O}_{2} / \mathrm{CO}_{2}$ recycle coal combustion, Fuel 2001; 80: 2117-21.

54. $\mathrm{Hu} \mathrm{Y}$, Naito $\mathrm{S}$, Kobayashi N, Hasatani M. $\mathrm{CO}_{2}, \mathrm{NO}_{\mathrm{X}}$ and $\mathrm{SO}_{2}$ emissions from the combustion of coal with high oxygen concentrations gases. Fuel 2000; 79: 1925-32.

55. Hu YQ, Kobayashi N, Hasatani M. Effects of coal properties on recycled-NO $\mathrm{N}_{\mathrm{X}}$ reduction in coal combustion with $\mathrm{O}_{2} /$ recycled flue gas. Energy Conversion and Management 2003; 44: 2331-40.

56. Lee B, Song H, Kim R, Kim S, Kim Y, Chang Y, Jeon Z. Simulation of the influence of the coal volatile matter content on fuel $\mathrm{NO}$ emissions in a drop-tube furnace. Energy and Fuels 2010; 24: 4333-434. 
57. Zhang L, Binner E, Qiao Y, Li C-Z. In situ diagnostics of Victoria brown coal combustion in $\mathrm{O}_{2} / \mathrm{N}_{2}$ and $\mathrm{O}_{2} / \mathrm{CO}_{2}$ in a drop-tube furnace. Fuel 2010; 89: 270312.

58. Chui EH, Gao H. Estimation of $\mathrm{NO}_{\mathrm{X}}$ emissions from coal-fired utility boilers. Fuel 2010; 89: 2977-84.

59. Gharebaghi M, Irons RMA, Ma L, Pourkashanian M, Pranzitelli A. Large eddy simulation of oxy-coal combustion in an industrial combustion test facility. International Journal of Greenhouse Gas Control 2011, 5S: S100-10. 
Tables

Table 1. Proximate and ultimate analysis of the coals used

\begin{tabular}{|c|c|c|}
\hline Sample & $\mathrm{AC}$ & SAB \\
\hline $\begin{array}{l}\text { Origin } \\
\text { Rank }\end{array}$ & $\begin{array}{c}\text { Spain } \\
\text { an }\end{array}$ & $\begin{array}{l}\text { S. Africa } \\
\text { hvb }\end{array}$ \\
\hline \multicolumn{3}{|l|}{ Proximate Analysis (wt.\%, db) } \\
\hline Ash & 14.2 & 15.0 \\
\hline Volatile matter & 3.6 & 29.9 \\
\hline Fixed carbon $^{\mathrm{a}}$ & 82.2 & 55.1 \\
\hline \multicolumn{3}{|l|}{ Ultimate Analysis (wt. \%, daf) } \\
\hline $\mathrm{C}$ & 94.7 & 81.5 \\
\hline $\mathrm{H}$ & 1.6 & 5.0 \\
\hline $\mathrm{N}$ & 1.0 & 2.1 \\
\hline $\mathrm{S}$ & 0.7 & 0.9 \\
\hline $\mathrm{O}^{\mathrm{a}}$ & 2.0 & 10.5 \\
\hline High heating value (MJ/kg, db) & 29.2 & 27.8 \\
\hline
\end{tabular}


Table 2. Devolatilisation and combustion reactivity data inputs for the CFD code

\begin{tabular}{cccc}
\hline Parameter/case & Default & AC & SAB \\
\hline Devolatilisation model & Single rate & Single rate & Single rate \\
Pre-exponential factor $(1 / \mathrm{s})$ & $3.82 \mathrm{E} 4$ & $3.07 \mathrm{E} 14$ & $4.68 \mathrm{E} 11$ \\
Activation energy $(\mathrm{kJ} / \mathrm{mol})$ & 74.0 & 228.6 & 155.9 \\
Combustion model & Intrinsic & Intrinsic & Intrinsic \\
\hline Kinetic-limited rate pre-exponential factor $(\mathrm{g} / \mathrm{cm} \mathrm{s})$ & 0.03 & 0.03 & 0.03 \\
Kinetic-limited rate activation energy $(\mathrm{kJ} / \mathrm{mol})$ & 179 & $155 \pm 10$ & $155 \pm 10$ \\
Specific internal area $\left(\mathrm{m}^{2} / \mathrm{g}\right)$ & 300 & 40 & 100 \\
Burning mode, alpha & 0 & 0.25 & 0.25 \\
\hline
\end{tabular}


Table 3. Inputs for the CFD code for the gases and coal feed rates

\begin{tabular}{cccc}
\hline \multirow{2}{*}{ Atmosphere } & $\begin{array}{c}\text { Gas inlet } \\
(\mathrm{g} / \mathrm{min})\end{array}$ & \multicolumn{2}{c}{ Coal mass flow rate $(\mathrm{g} / \mathrm{min})$} \\
\cline { 3 - 4 } & & $\mathrm{AC}$ & $\mathrm{SAB}$ \\
\hline \hline $21 \% \mathrm{O}_{2} / 79 \% \mathrm{~N}_{2}$ & 1.548 & 0.099 & 0.105 \\
$21 \% \mathrm{O}_{2} / 79 \% \mathrm{CO}_{2}$ & 2.118 & 0.099 & 0.105 \\
$30 \% \mathrm{O}_{2} / 70 \% \mathrm{CO}_{2}$ & 2.058 & 0.138 & 0.147 \\
$35 \% \mathrm{O}_{2} / 65 \% \mathrm{CO}_{2}$ & 2.016 & 0.160 & 0.175 \\
\hline
\end{tabular}


Table 4. Comparison between experimental and predicted char and volatile nitrogen content (in mass fraction) after coal devolatilisation at $10^{5} \mathrm{~K} / \mathrm{s}$ and $1273 \mathrm{~K}$.

\begin{tabular}{ccccccc}
\hline \multirow{2}{*}{ Coal } & \multicolumn{2}{c}{ Experimental-N } & \multicolumn{2}{c}{ Experimental-CO } & \multicolumn{2}{c}{ Predicted FG-DVC } \\
\cline { 2 - 6 } & N-char & N-volatile & N-char & N-volatile. & N-char & N-volatile. \\
\hline \hline AC & 0.0098 & 0.0652 & 0.0097 & 0.059 & 0.0121 & 0.0087 \\
SAB & 0.0238 & 0.0264 & 0.0226 & 0.0270 & 0.0227 & 0.0168 \\
\hline
\end{tabular}


Table 5. FG-DVC predicted char and volatile nitrogen content (in mass fraction) after coal devolatilisation at different temperatures $(1273-1773 \mathrm{~K})$ and heating rates $\left(10^{4}-10^{6}\right.$ $\mathrm{K} / \mathrm{s})$

\begin{tabular}{c|c|cccccc}
\hline \multirow{2}{*}{ Coal } & \multirow{2}{*}{$\begin{array}{c}\text { Heating } \\
\text { rate }\end{array}$} & \multicolumn{2}{l}{ Temperature: $1273 \mathrm{~K}$} & Temperature: $1523 \mathrm{~K}$ & \multicolumn{2}{l}{ Temperatura: 1773 K } \\
\cline { 3 - 8 } & & N-char & N-volatile & N-char & N-volatile & N-char & N-volatile \\
\hline \hline \multirow{2}{*}{$\mathrm{AC}$} & $10^{4} \mathrm{~K} \mathrm{~s}^{-1}$ & 0.0126 & 0.0074 & 0.0126 & 0.0070 & 0.0125 & 0.0070 \\
& $10^{5} \mathrm{~K} \mathrm{~s}^{-1}$ & 0.0125 & 0.0087 & 0.0125 & 0.0079 & 0.0125 & 0.0079 \\
& $10^{6} \mathrm{~K} \mathrm{~s}^{-1}$ & 0.0123 & 0.0092 & 0.0123 & 0.0091 & 0.0123 & 0.0091 \\
\hline \multirow{2}{*}{$\mathrm{SAB}$} & $10^{4} \mathrm{~K} \mathrm{~s}^{-1}$ & 0.0249 & 0.0160 & 0.0244 & 0.0170 & 0.0244 & 0.0170 \\
& $10^{5} \mathrm{~K} \mathrm{~s}^{-1}$ & 0.0247 & 0.0167 & 0.0244 & 0.0174 & 0.0244 & 0.0174 \\
& $10^{6} \mathrm{~K} \mathrm{~s}^{-1}$ & 0.0246 & 0.0171 & 0.0243 & 0.0178 & 0.0243 & 0.0178 \\
\hline
\end{tabular}


Table 6. FG-DVC predicted coal devolatilisation kinetics at different temperatures $(1273-1573 \mathrm{~K})$ and heating rates $\left(10^{4}-10^{6} \mathrm{~K} / \mathrm{s}\right)$ for coal $\mathrm{AC}\left(\mathrm{E}_{\mathrm{a}}: \mathrm{kJ} / \mathrm{mol} ; \mathrm{A}: 1 / \mathrm{s}\right)$

\begin{tabular}{cccc}
\hline \multirow{2}{*}{ Temperature $(\mathrm{K})$} & \multicolumn{3}{c}{ Heating rate } \\
\cline { 2 - 4 } 1273 & $10^{4} \mathrm{~K} \mathrm{~s}^{-1}$ & $10^{5} \mathrm{~K} \mathrm{~s}^{-1}$ & $10^{6} \mathrm{~K} \mathrm{~s}^{-1}$ \\
\hline \hline \multirow{2}{*}{1523} & $\mathrm{~A}: 7.11 \mathrm{E} 14$ & $\mathrm{~A}: 3.07 \mathrm{E} 14$ & $\mathrm{~A}: 1.55 \mathrm{E} 13$ \\
& $\mathrm{E}_{\mathrm{a}}: 245.5 \pm 2.9$ & $\mathrm{E}_{\mathrm{a}}: 228.6 \pm 1.5$ & $\mathrm{E}_{\mathrm{a}}: 200.0 \pm 2.5$ \\
\hline \multirow{2}{*}{1773} & $\mathrm{~A}: 4.99 \mathrm{E} 12$ & $\mathrm{~A}: 1.00 \mathrm{E} 12$ & $\mathrm{~A}: 3.69 \mathrm{E} 11$ \\
& $\mathrm{E}_{\mathrm{a}}: 218.0 \pm 1.4$ & $\mathrm{E}_{\mathrm{a}}: 199.8 \pm 3.0$ & $\mathrm{E}_{\mathrm{a}}: 183.1 \pm 1.2$ \\
\hline \multirow{2}{*}{$\mathrm{A}: 1.80 \mathrm{E} 11$} & $\mathrm{~A}: 1.91 \mathrm{E} 11$ & $\mathrm{~A}: 1.13 \mathrm{E} 11$ \\
& $\mathrm{E}_{\mathrm{a}}: 173.6 \pm 3.2$ & $\mathrm{E}_{\mathrm{a}}: 170.0 \pm 2.3$ & $\mathrm{E}_{\mathrm{a}}: 161.9 \pm 3.3$ \\
\hline
\end{tabular}


Table 7. FG-DVC predicted coal devolatilisation kinetics at different temperatures $(1273-1573 \mathrm{~K})$ and heating rates $\left(10^{4}-10^{6} \mathrm{~K} / \mathrm{s}\right)$ for coal SAB $\left(\mathrm{E}_{\mathrm{a}}: \mathrm{kJ} / \mathrm{mol} ; \mathrm{A}: 1 / \mathrm{s}\right)$

\begin{tabular}{cccc}
\hline \multirow{2}{*}{ Temperature $(\mathrm{K})$} & \multicolumn{3}{c}{ Heating rate } \\
\cline { 2 - 4 } & $10^{4} \mathrm{~K} \mathrm{~s}^{-1}$ & $10^{5} \mathrm{~K} \mathrm{~s}^{-1}$ & $10^{6} \mathrm{~K} \mathrm{~s}^{-1}$ \\
\hline \multirow{2}{*}{1273} & $\mathrm{~A}: 3.79 \mathrm{E} 12$ & $\mathrm{~A}: 4.68 \mathrm{E} 11$ & $\mathrm{~A}: 4.38 \mathrm{E} 11$ \\
& $\mathrm{E}_{\mathrm{a}}: 171.6 \pm 2.7$ & $\mathrm{E}_{\mathrm{a}}: 155.9 \pm 2.6$ & $\mathrm{E}_{\mathrm{a}}: 139.0 \pm 1.8$ \\
\hline \multirow{2}{*}{1523} & $\mathrm{~A}: 9.14 \mathrm{E} 11$ & $\mathrm{~A}: 4.28 \mathrm{E} 11$ & $\mathrm{~A}: 2.40 \mathrm{E} 11$ \\
& $\mathrm{E}_{\mathrm{a}}: 160.6 \pm 1.6$ & $\mathrm{E}_{\mathrm{a}}: 147.5 \pm 3.2$ & $\mathrm{E}_{\mathrm{a}}: 133.7 \pm 1.5$ \\
\hline \multirow{2}{*}{1773} & $\mathrm{~A}: 2.62 \mathrm{E} 11$ & $\mathrm{~A}: 2.09 \mathrm{E} 11$ & $\mathrm{~A}: 1.66 \mathrm{E} 11$ \\
& $\mathrm{E}_{\mathrm{a}}: 134.0 \pm 3.9$ & $\mathrm{E}_{\mathrm{a}}: 132.8 \pm 4.2$ & $\mathrm{E}_{\mathrm{a}}: 130.0 \pm 6.0$ \\
\hline
\end{tabular}


Table 8. FG-DVC predicted $\mathrm{NH}_{3}$ and $\mathrm{HCN}$ kinetics release from tar-N at different temperatures $(1273-1773 \mathrm{~K})$ and heating rates $\left(10^{4}-10^{6} \mathrm{~K} / \mathrm{s}\right)$ for coal $\mathrm{AC}$. $\left(\mathrm{E}_{\mathrm{a}}: \mathrm{kJ} / \mathrm{mol}\right.$; A: $1 / \mathrm{s})$

\begin{tabular}{cccc}
\hline \multirow{2}{*}{$\begin{array}{c}\text { Temperature } \\
(\mathrm{K})\end{array}$} & $10^{4} \mathrm{~K} \mathrm{~s}^{-1}$ & $10^{5} \mathrm{~K} \mathrm{~s}^{-1}$ & \multicolumn{1}{c}{$10^{6} \mathrm{Ks}^{-1}$} \\
\cline { 2 - 4 } & $\mathrm{A}_{\mathrm{NH} 3}: 1.63 \mathrm{E} 8$ & $\mathrm{~A}_{\mathrm{NH} 3}: 3.31 \mathrm{E} 8$ & $\mathrm{~A}_{\mathrm{NH} 3}: 9.55 \mathrm{E} 8$ \\
\hline \multirow{2}{*}{1273} & $\mathrm{Ea}_{\mathrm{NH} 3}: 162.8 \pm 4.8$ & $\mathrm{Ea}_{\mathrm{NH} 3}: 166.0 \pm 4.5$ & $\mathrm{Ea}_{\mathrm{NH} 3}: 172.3 \pm 5.0$ \\
& $\mathrm{~A}_{\mathrm{HCN}}: 3.52 \mathrm{E} 9$ & $\mathrm{~A}_{\mathrm{HCN}}: 8.10 \mathrm{E} 10$ & $\mathrm{~A}_{\mathrm{HCN}}: 3.32 \mathrm{E} 11$ \\
& $\mathrm{Ea}_{\mathrm{HCN}}: 247.6 \pm 3.6$ & $\mathrm{Ea}_{\mathrm{HCN}}: 251.0 \pm 4.8$ & $\mathrm{Ea}_{\mathrm{HCN}}: 259.3 \pm 5.6$ \\
\hline \multirow{3}{*}{1523} & $\mathrm{~A}_{\mathrm{NH} 3}: 2.06 \mathrm{E} 8$ & $\mathrm{~A}_{\mathrm{NH} 3}: 6.6 \mathrm{E} 8$ & $\mathrm{~A}_{\mathrm{NH} 3}: 1.15 \mathrm{E} 9$ \\
& $\mathrm{Ea}_{\mathrm{NH} 3}: 169.4 \pm 5.0$ & $\mathrm{Ea}_{\mathrm{NH} 3}: 170.5 \pm 3.2$ & $\mathrm{Ea}_{\mathrm{NH} 3}: 174.0 \pm 4.4$ \\
& $\mathrm{~A}_{\mathrm{HCN}}: 3.60 \mathrm{E} 9$ & $\mathrm{~A}_{\mathrm{HCN}}: 4.63 \mathrm{E} 10$ & $\mathrm{~A}_{\mathrm{HCN}}: 9.65 \mathrm{E} 10$ \\
& $\mathrm{Ea}_{\mathrm{HCN}}: 242.0 \pm 2.3$ & $\mathrm{Ea}_{\mathrm{HCN}}: 246.8 \pm 3.7$ & $\mathrm{Ea}_{\mathrm{HCN}}: 251.4 \pm 4.1$ \\
\hline \multirow{4}{*}{1773} & $\mathrm{~A}_{\mathrm{NH} 3}: 3.14 \mathrm{E} 8$ & $\mathrm{~A}_{\mathrm{NH} 3}: 1.85 \mathrm{E} 9$ & $\mathrm{~A}_{\mathrm{NH} 3}: 1.29 \mathrm{E} 9$ \\
& $\mathrm{Ea}_{\mathrm{NH} 3}: 166.3 \pm 2.6$ & $\mathrm{Ea}_{\mathrm{NH} 3}: 169.2 \pm 3.6$ & $\mathrm{Ea}_{\mathrm{NH} 3}: 171.2 \pm 4.0$ \\
& $\mathrm{~A}_{\mathrm{HCN}}: 6.33 \mathrm{E} 9$ & $\mathrm{~A}_{\mathrm{HCN}}: 3.28 \mathrm{E} 10$ & $\mathrm{~A}_{\mathrm{HCN}}: 6.26 \mathrm{E} 10$ \\
& $\mathrm{Ea}_{\mathrm{HCN}}: 241.3 \pm 3.7$ & $\mathrm{Ea}_{\mathrm{HCN}}: 243.3 \pm 2.6$ & $\mathrm{Ea}_{\mathrm{HCN}}: 246.2 \pm 4.9$ \\
\hline
\end{tabular}


Table 9. FG-DVC predicted $\mathrm{NH}_{3}$ and $\mathrm{HCN}$ kinetics release from tar- $\mathrm{N}$ at different temperatures $(1273-1773 \mathrm{~K})$ and heating rates $\left(10^{4}-10^{6} \mathrm{~K} / \mathrm{s}\right)$ for coal SAB. $\left(\mathrm{E}_{\mathrm{a}}: \mathrm{kJ} / \mathrm{mol}\right.$; A: $1 / \mathrm{s})$

\begin{tabular}{cccc}
\hline \multirow{2}{*}{$\begin{array}{c}\text { Temperature } \\
(\mathrm{K})\end{array}$} & \multicolumn{3}{c}{ Heating rate } \\
\cline { 2 - 4 } & $10^{4} \mathrm{~K} \mathrm{~s}^{-1}$ & $10^{5} \mathrm{~K} \mathrm{~s}^{-1}$ & $10^{6} \mathrm{~K} \mathrm{~s}^{-1}$ \\
\hline \hline \multirow{4}{*}{1273} & $\mathrm{~A}_{\mathrm{NH} 3}: 1.34 \mathrm{E} 10$ & $\mathrm{~A}_{\mathrm{NH} 3}: 2.61 \mathrm{E} 10$ & $\mathrm{~A}_{\mathrm{NH} 3}: 3.38 \mathrm{E} 10$ \\
& $\mathrm{Ea}_{\mathrm{NH} 3}: 190.5 \pm 3.7$ & $\mathrm{Ea}_{\mathrm{NH} 3}: 194.7 \pm 4.2$ & $\mathrm{Ea}_{\mathrm{NH} 3}: 196.4 \pm 2.8$ \\
& $\mathrm{~A}_{\mathrm{HCN}}: 6.29 \mathrm{E} 9$ & $\mathrm{~A}_{\mathrm{HCN}}: 4.47 \mathrm{E} 10$ & $\mathrm{~A}_{\mathrm{HCN}}: 9.25 \mathrm{E} 10$ \\
& $\mathrm{Ea}_{\mathrm{HCN}}: 228.6 \pm 2.5$ & $\mathrm{Ea}_{\mathrm{HCN}}: 232.6 \pm 3.1$ & $\mathrm{Ea}_{\mathrm{HCN}}: 237.9 \pm 4.0$ \\
\hline \multirow{4}{*}{1523} & $\mathrm{~A}_{\mathrm{NH} 3}: 7.57 \mathrm{E} 8$ & $\mathrm{~A}_{\mathrm{NH} 3}: 1.85 \mathrm{E} 10$ & $\mathrm{~A}_{\mathrm{NH} 3}: 3.85 \mathrm{E} 10$ \\
& $\mathrm{Ea}_{\mathrm{NH} 3}: 186.5 \pm 2.6$ & $\mathrm{Ea}_{\mathrm{NH} 3}: 192.2 \pm 2.8$ & $\mathrm{Ea}_{\mathrm{NH} 3}: 197.4 \pm 3.5$ \\
& $\mathrm{~A}_{\mathrm{HCN}}: 1.05 \mathrm{E} 9$ & $\mathrm{~A}_{\mathrm{HCN}}: 3.31 \mathrm{E} 10$ & $\mathrm{~A}_{\mathrm{HCN}}: 4.96 \mathrm{E} 10$ \\
& $\mathrm{Ea}_{\mathrm{HCN}}: 223.0 \pm 4.5$ & $\mathrm{Ea}_{\mathrm{HCN}}: 229.9 \pm 1.5$ & $\mathrm{Ea}_{\mathrm{HCN}}: 232.2 \pm 4.8$ \\
\hline & $\mathrm{A}_{\mathrm{NH} 3}: 6.17 \mathrm{E} 8$ & $\mathrm{~A}_{\mathrm{NH} 3}: 1.88 \mathrm{E} 10$ & $\mathrm{~A}_{\mathrm{NH} 3}: 3.02 \mathrm{E} 10$ \\
& $\mathrm{Ea}_{\mathrm{NH} 3}: 185.4 \pm 3.6$ & $\mathrm{Ea}_{\mathrm{NH} 3}: 192.3 \pm 1.7$ & $\mathrm{Ea}_{\mathrm{NH} 3}: 195.5 \pm 2.9$ \\
& $\mathrm{~A}_{\mathrm{HCN}}: 1.08 \mathrm{E} 9$ & $\mathrm{~A}_{\mathrm{HCN}}: 3.79 \mathrm{E} 10$ & $\mathrm{~A}_{\mathrm{HCN}}: 3.26 \mathrm{E} 10$ \\
& $\mathrm{Ea}_{\mathrm{HCN}}: 221.3 \pm 4.8$ & $\mathrm{Ea}_{\mathrm{HCN}}: 231.1 \pm 2.3$ & $\mathrm{Ea}_{\mathrm{HCN}}: 228.2 \pm 3.9$ \\
\hline
\end{tabular}


Table 10. Experimental burnout and NO emissions of coals AC and SAB under different combustion atmospheres at an equivalence ratio of 0.8 ( $25 \%$ oxygen excess)

\begin{tabular}{ccccc}
\hline & $21 \% \mathrm{O}_{2} / 79 \% \mathrm{~N}_{2}$ & $21 \% \mathrm{O}_{2} / 79 \% \mathrm{CO}_{2}$ & $30 \% \mathrm{O}_{2} / 70 \% \mathrm{CO}_{2}$ & $35 \% \mathrm{O}_{2} / 65 \% \mathrm{CO}_{2}$ \\
\hline \hline Burnout-AC & 76.8 & 69.4 & 79.7 & 81.6 \\
Burnout-SAB & 92.5 & 90.2 & 93.9 & 94.7 \\
\hline NO emisions-AC & $247 \pm 12$ & $223 \pm 11$ & $287 \pm 14$ & $372 \pm 19$ \\
NO emissions -SAB & $400 \pm 20$ & $365 \pm 18$ & $498 \pm 25$ & $474 \pm 24$ \\
\hline
\end{tabular}


Table 11. Comparison between experimental and numerical NO emissions (ppm, dry basis) for coals AC and SAB in all the atmospheres studied

\begin{tabular}{lcccccc}
\hline & \multicolumn{7}{c}{$\mathrm{AC}$} & & $\mathrm{SAB}$ & \\
\cline { 2 - 7 } & Experimental & Prediction 1 & Prediction 2 & Experimental & Prediction 1 & Prediction 2 \\
\hline $21 \% \mathrm{O}_{2} / 79 \% \mathrm{~N}_{2}$ & $247 \pm 12$ & 205 & 226 & $400 \pm 20$ & 500 & 480 \\
$21 \% \mathrm{O}_{2} / 79 \% \mathrm{CO}_{2}$ & $223 \pm 11$ & 175 & 198 & $365 \pm 18$ & 381 & 368 \\
$30 \% \mathrm{O}_{2} / 70 \% \mathrm{CO}_{2}$ & $287 \pm 14$ & 297 & 330 & $498 \pm 25$ & 522 & 519 \\
$35 \% \mathrm{O}_{2} / 65 \% \mathrm{CO}_{2}$ & $372 \pm 19$ & 377 & 418 & $474 \pm 24$ & 526 & 521 \\
\hline
\end{tabular}




\section{Figure captions}

Fig 1. Predicted $(a, b)$ volatile release curves and (c, d) $\mathrm{HCN} / \mathrm{NH}_{3}$ evolution during devolatilisation for a final temperature of $1273 \mathrm{~K}$ and a heating rate of $10^{5} \mathrm{~K} / \mathrm{s}$ for $\mathrm{AC}$ and SAB.

Fig. 2. FG-DVC predicted char yield $(a, b)$ and N-char yield (c, d) after devolatilisation at different temperatures $(1273-1773 \mathrm{~K})$ and heating rates $\left(10^{4}-10^{6} \mathrm{~K} / \mathrm{s}\right)$ for coals $\mathrm{AC}$ and SAB.

Fig 3. Burnout of $\mathrm{AC}$ and $\mathrm{SAB}$ under different combustion atmospheres at various equivalence ratios.

Fig 4. NO concentration (ppm) of AC and SAB under different combustion atmospheres at various equivalence ratios.

Fig 5. Predicted temperature $(\mathrm{K}), \mathrm{O}_{2}$ concentration (\%) and char burning rate $(\mathrm{kg} / \mathrm{s})$ inside the entrained flow reactor during SAB combustion with Fluent default devolatilisation kinetics (a, b, c) and FG-DVC kinetics (d, e, f). Combustion atmospheres: $21 \% \mathrm{O}_{2} / 79 \% \mathrm{~N}_{2}$ (I), $21 \% \mathrm{O}_{2} / 79 \% \mathrm{CO}_{2}$ (II), $30 \% \mathrm{O}_{2} / 70 \% \mathrm{CO}_{2}$ (III) and $35 \% \mathrm{O}_{2} / 65 \% \mathrm{CO}_{2}$ (IV). Length scale for (a-f) is $40 \mathrm{~cm}$.

Fig 6. Comparison between experimental and numerical coal burnouts and oxygen concentrations for SAB.

Fig. 7. Predicted temperature $(\mathrm{K}), \mathrm{O}_{2}$ concentration $(\%)$ and char burning rate $(\mathrm{kg} / \mathrm{s})$ inside the entrained flow reactor during $\mathrm{AC}$ combustion with Fluent default devolatilisation kinetics (a, b, c) and FG-DVC kinetics (d, e, f). Combustion atmospheres: $21 \% \mathrm{O}_{2} / 79 \% \mathrm{~N}_{2}$ (I), $21 \% \mathrm{O}_{2} / 79 \% \mathrm{CO}_{2}$ (II), $30 \% \mathrm{O}_{2} / 70 \% \mathrm{CO}_{2}$ (III) and $35 \% \mathrm{O}_{2} / 65 \% \mathrm{CO}_{2}(\mathrm{IV})$. Length scale for (a-f) is $40 \mathrm{~cm}$.

Fig 8. Comparison between experimental and numerical coal burnouts and oxygen concentrations for AC. 

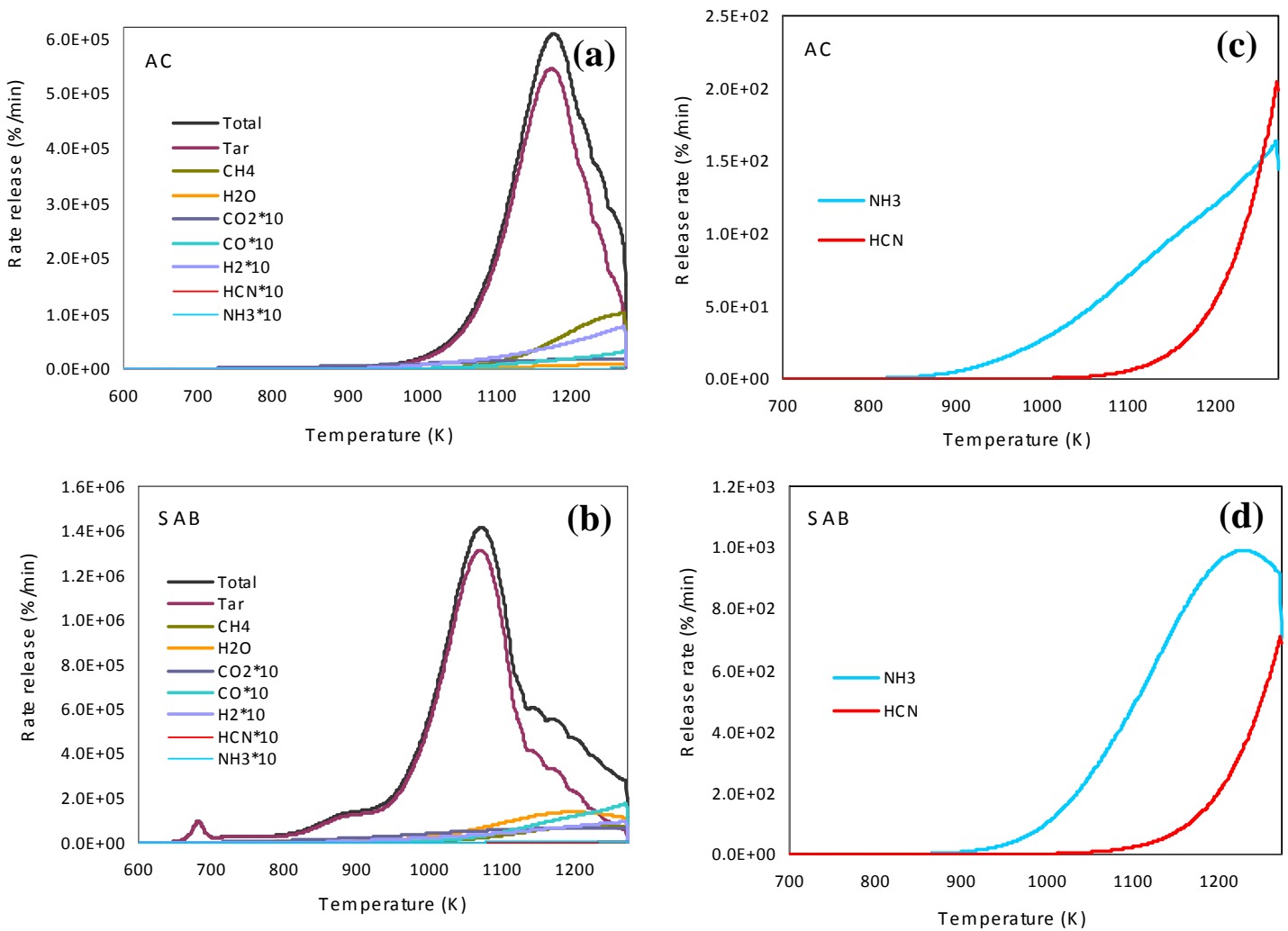

Figure 1. Predicted $(\mathrm{a}, \mathrm{b})$ volatile release curves and (c, d) $\mathrm{HCN} / \mathrm{NH}_{3}$ evolution during devolatilisation for a final temperature of $1273 \mathrm{~K}$ and a heating rate of $10^{5} \mathrm{~K} / \mathrm{s}$ for $\mathrm{AC}$ and $\mathrm{SAB}$. 

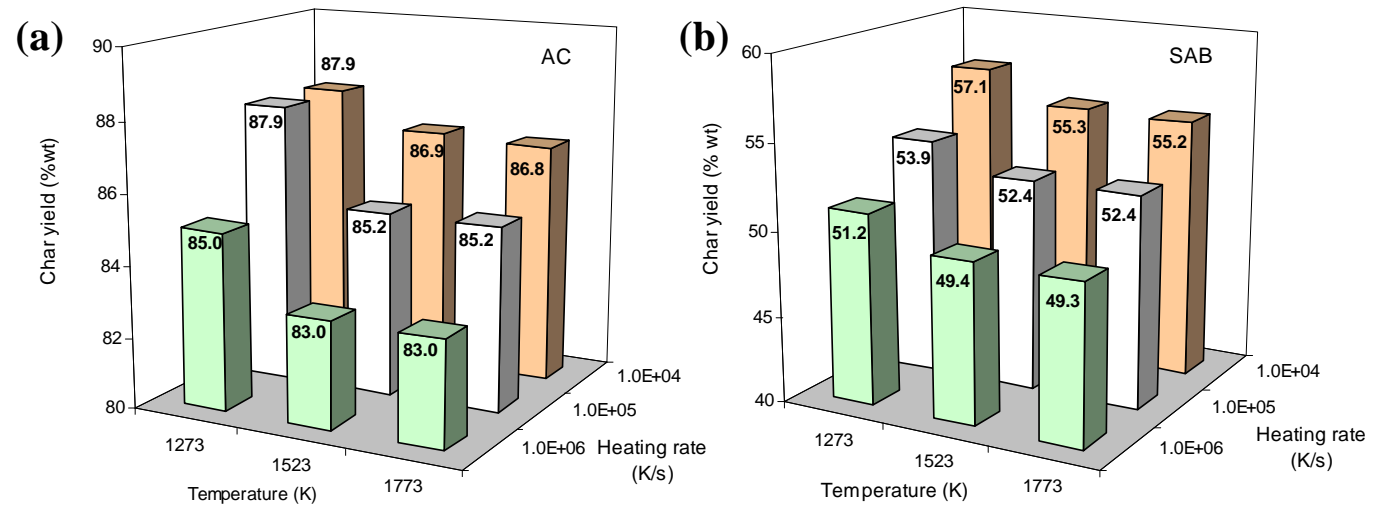

(c)

(d)
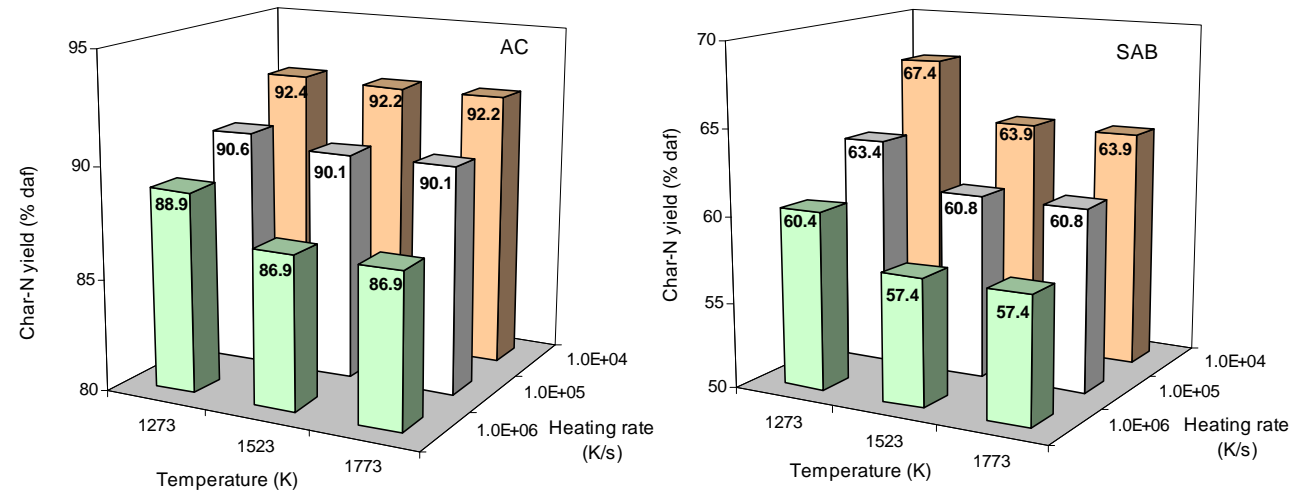

Figure 2. FG-DVC predicted char yield (a, b) and N-char yield (c, d) after devolatilisation at different temperatures $(1273-1773 \mathrm{~K})$ and heating rates $\left(10^{4}-10^{6} \mathrm{~K} / \mathrm{s}\right)$ for coals $\mathrm{AC}$ and $\mathrm{SAB}$. 

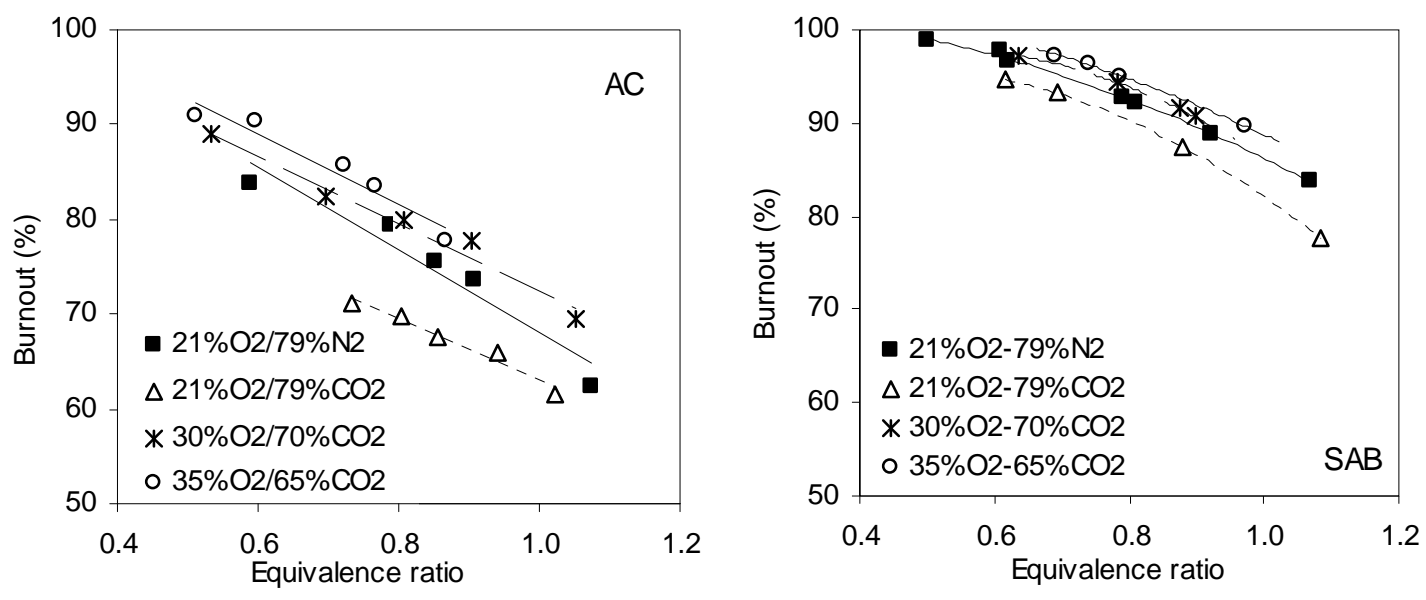

Figure 3. Burnout of $\mathrm{AC}$ and $\mathrm{SAB}$ under different combustion atmospheres at various equivalence ratios. 

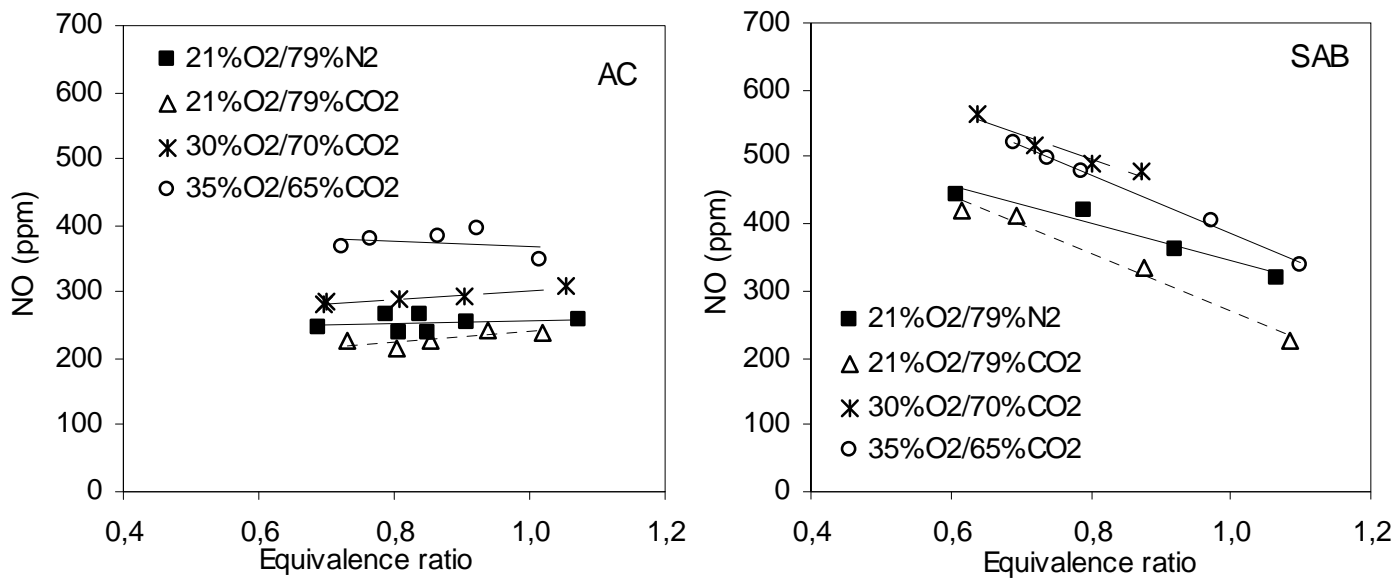

Figure 4. $\mathrm{NO}$ concentration (ppm) of $\mathrm{AC}$ and $\mathrm{SAB}$ under different combustion atmospheres at various equivalence ratios. 


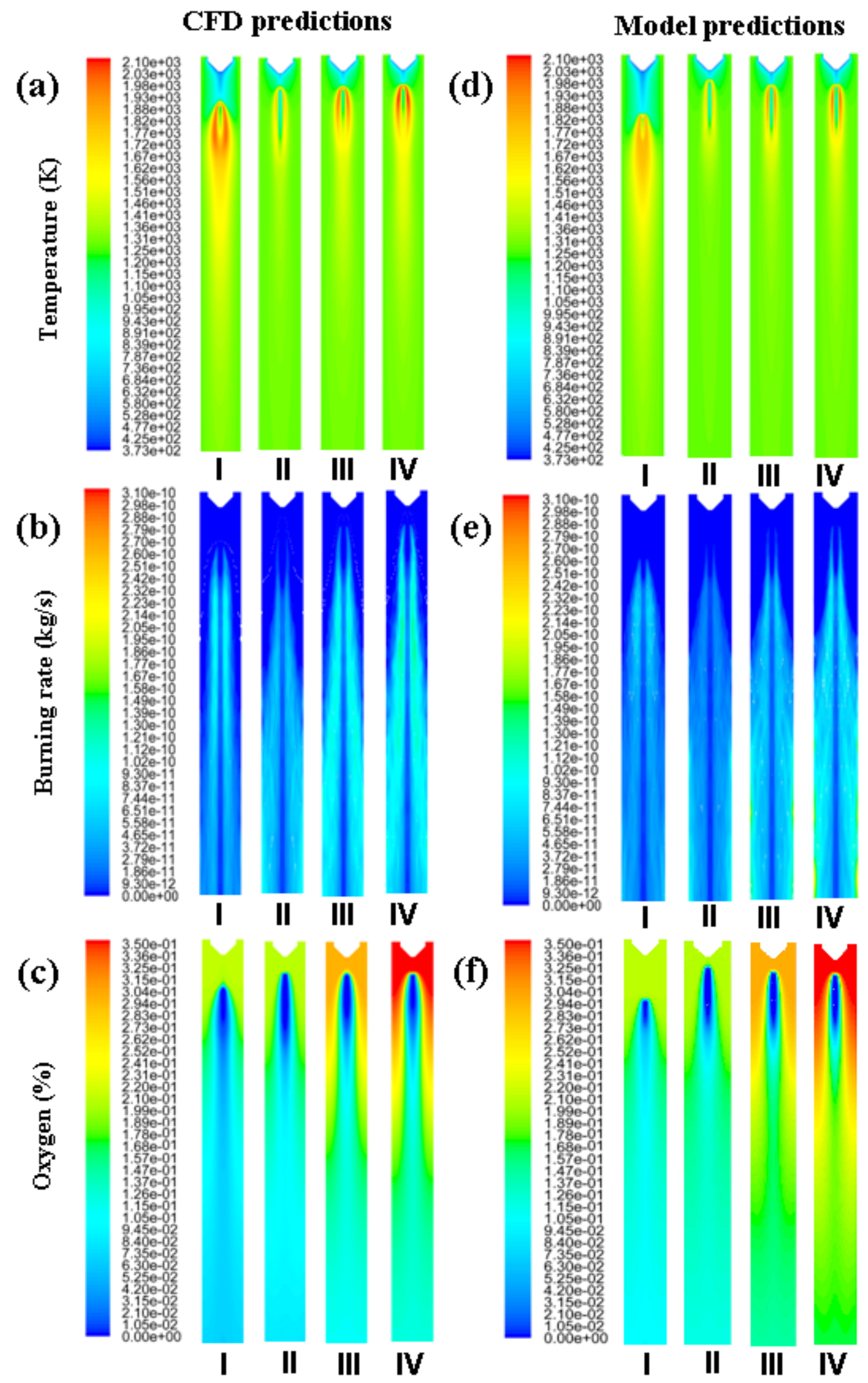


Figure 5. Predicted temperature $(\mathrm{K}), \mathrm{O}_{2}$ concentration (\%) and char burning rate $(\mathrm{kg} / \mathrm{s})$ inside the entrained flow reactor during SAB combustion with Fluent default devolatilisation kinetics (a, b, c) and FG-DVC kinetics (d, e, f). Combustion atmospheres: $21 \% \mathrm{O}_{2} / 79 \% \mathrm{~N}_{2}$ (I), $21 \% \mathrm{O}_{2} / 79 \% \mathrm{CO}_{2}$ (II), $30 \% \mathrm{O}_{2} / 70 \% \mathrm{CO}_{2}$ (III) and $35 \% \mathrm{O}_{2} / 65 \% \mathrm{CO}_{2}$ (IV). Length scale for (a-f) is $40 \mathrm{~cm}$. 

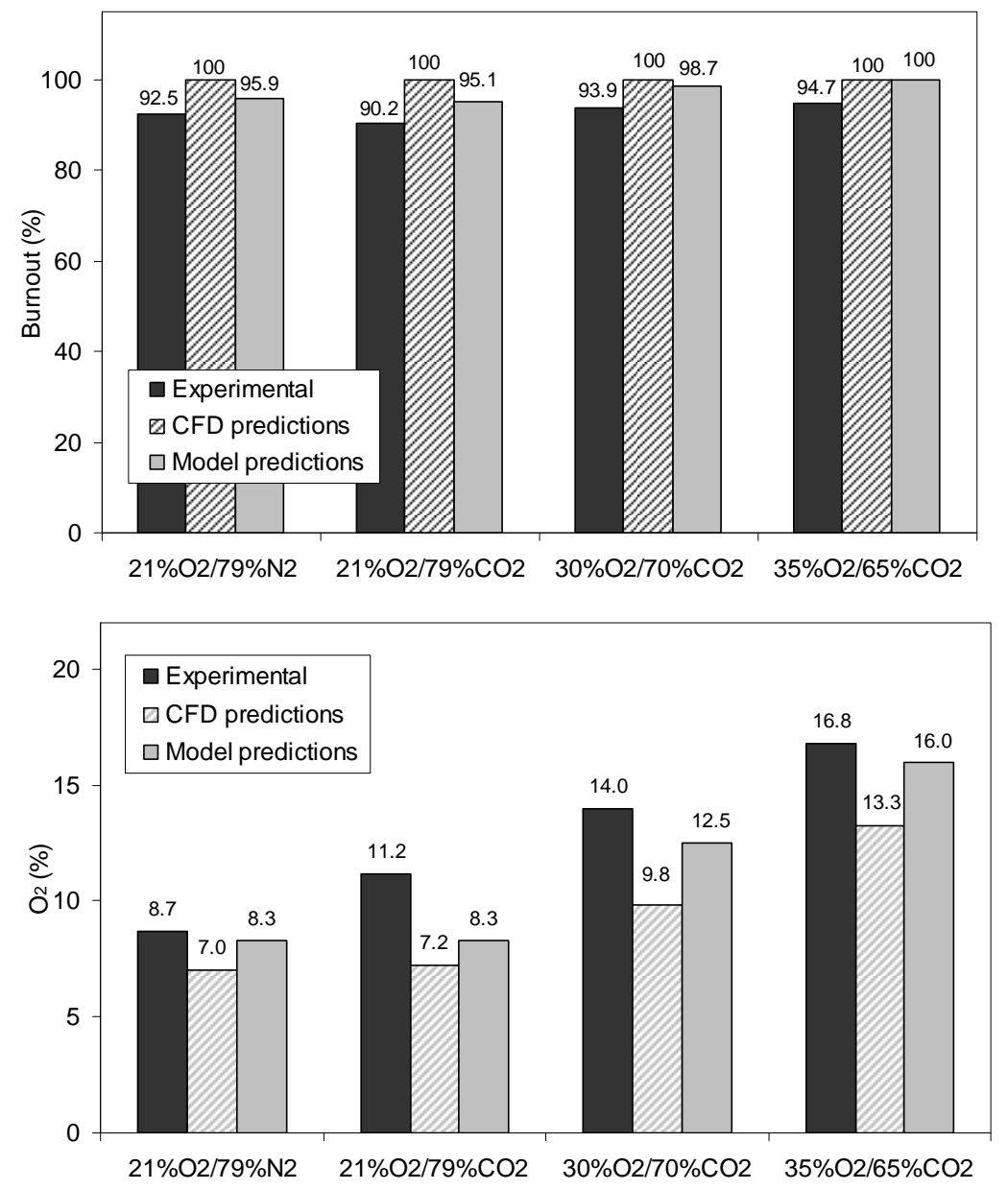

Figure 6. Comparison between experimental and numerical coal burnouts and oxygen concentrations for SAB. 
CFD predictions
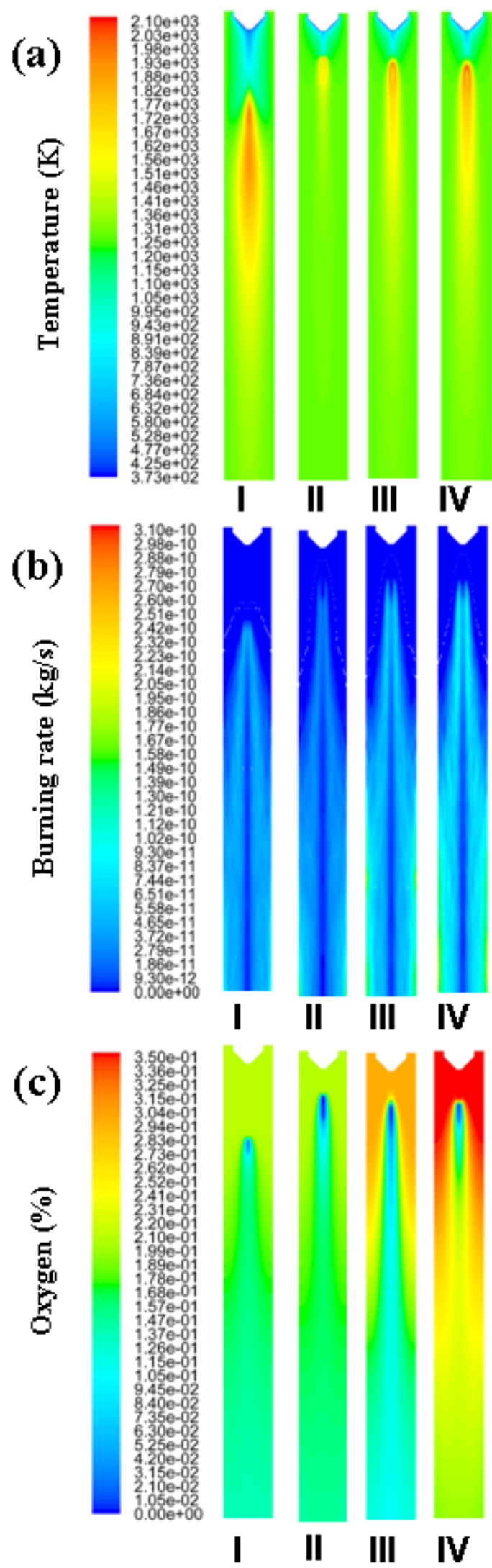

Model predictions

(d)
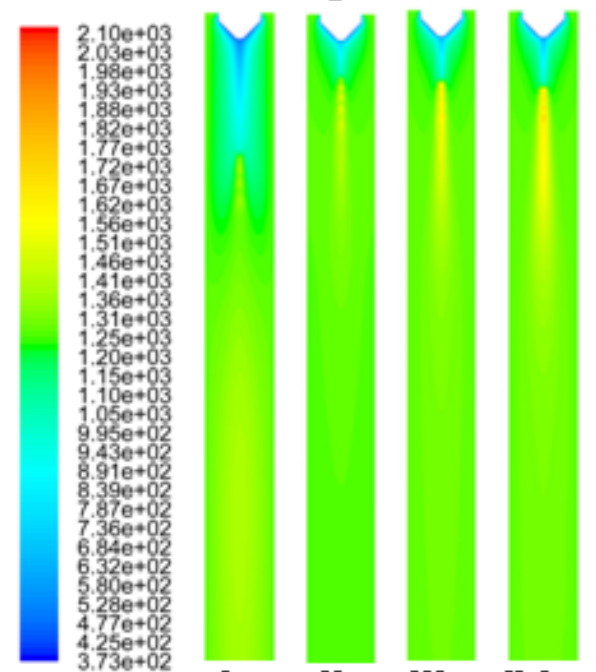

(e)

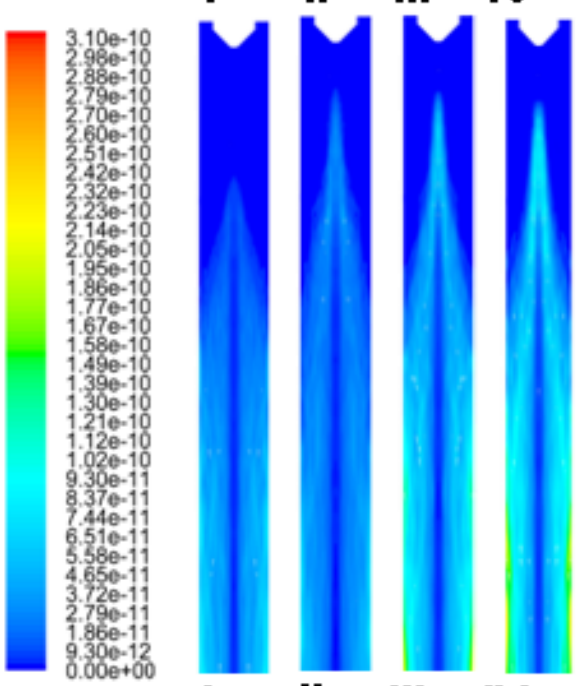

(f)

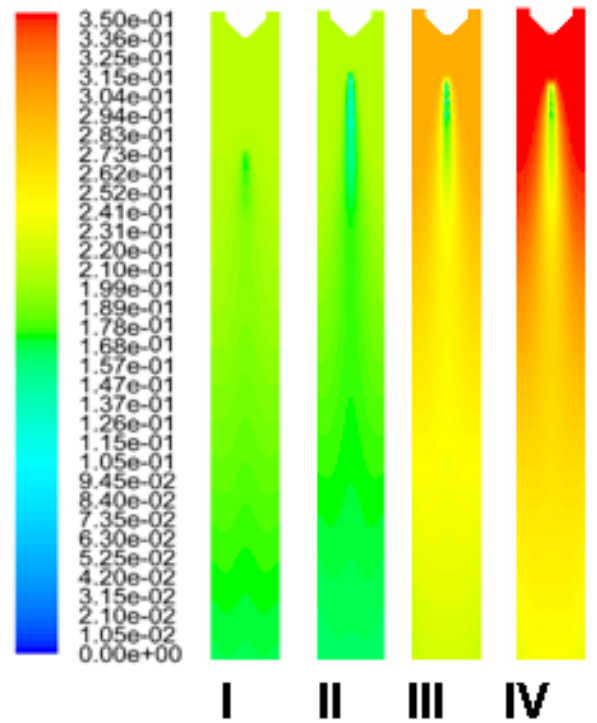


Figure 7. Predicted temperature $(\mathrm{K}), \mathrm{O}_{2}$ concentration $(\%)$ and char burning rate $(\mathrm{kg} / \mathrm{s})$ inside the entrained flow reactor during AC combustion with Fluent default devolatilisation kinetics (a, b, c) and FG-DVC kinetics (d, e, f). Combustion atmospheres: $21 \% \mathrm{O}_{2} / 79 \% \mathrm{~N}_{2}$ (I), $21 \% \mathrm{O}_{2} / 79 \% \mathrm{CO}_{2}$ (II), $30 \% \mathrm{O}_{2} / 70 \% \mathrm{CO}_{2}$ (III) and $35 \% \mathrm{O}_{2} / 65 \% \mathrm{CO}_{2}$ (IV). Length scale for (a-f) is $40 \mathrm{~cm}$. 

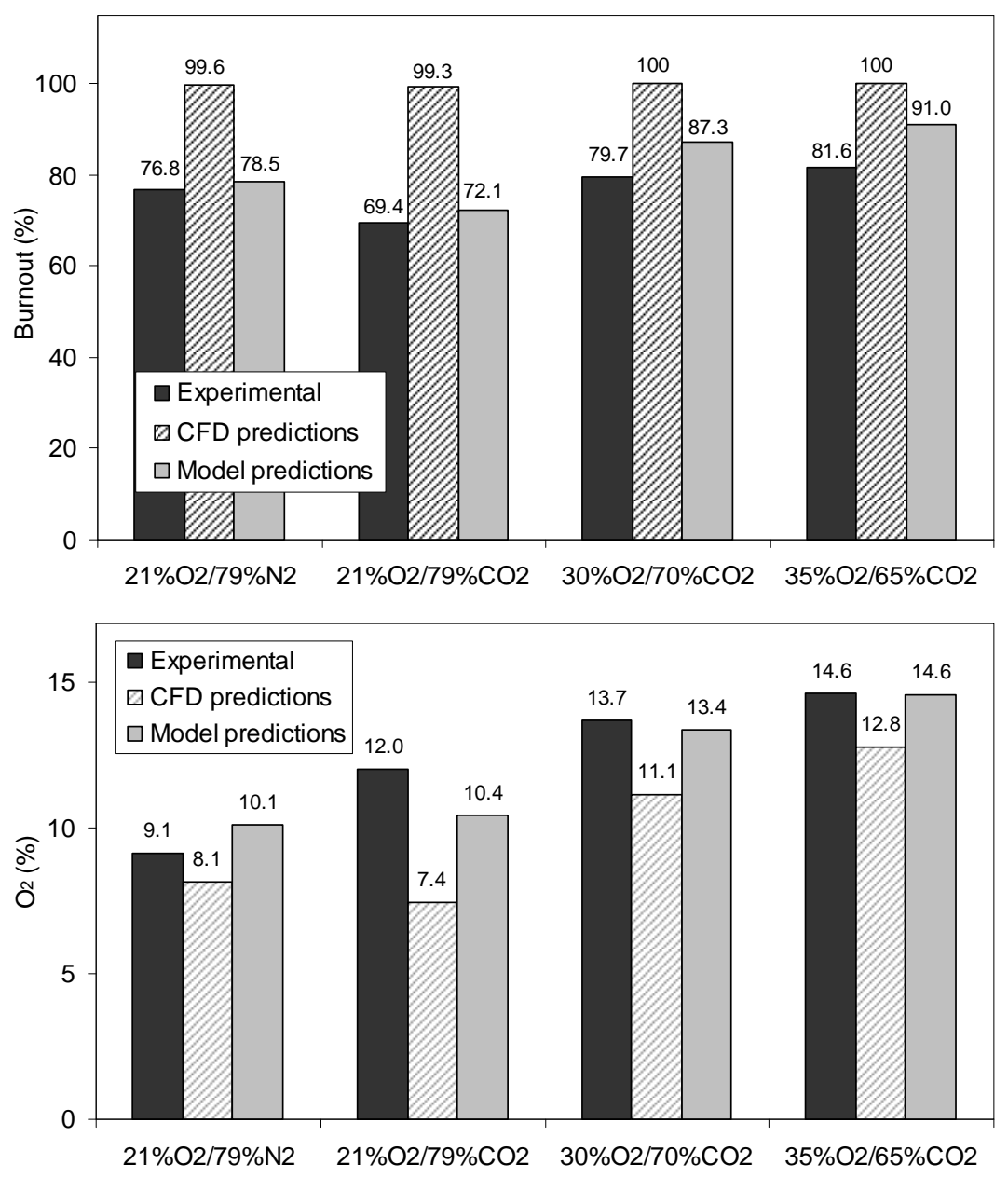

Figure 8. Comparison between experimental and numerical coal burnouts and oxygen concentrations for AC. 